\title{
A solar optical hyperspectral library of rare-earth-bearing minerals, rare-earth oxide powders, copper-bearing minerals and Apliki mine surface samples
}

\author{
Friederike Koerting ${ }^{1}$, Nicole Koellner ${ }^{1}$, Agnieszka Kuras ${ }^{1}$, Nina Kristin Boesche ${ }^{1}$, Christian Rogass ${ }^{1}$, \\ Christian Mielke ${ }^{1}$, Kirsten Elger ${ }^{1}$, and Uwe Altenberger ${ }^{2}$ \\ ${ }^{1}$ GFZ German Research Centre for Geosciences, Potsdam, 14473, Germany \\ ${ }^{2}$ University of Potsdam, Institute of Geosciences, Potsdam, 14476, Germany \\ Correspondence: Friederike Körting (koerting@gfz-potsdam.de) \\ and Nicole Koellner (nicolek@gfz-potsdam.de)
}

Received: 19 November 2019 - Discussion started: 9 December 2019

Revised: 1 February 2021 - Accepted: 2 February 2021 - Published: 9 March 2021

\begin{abstract}
Mineral resource exploration and mining is an essential part of today's high-tech industry. Elements such as rare-earth elements (REEs) and copper are, therefore, in high demand. Modern exploration techniques from multiple platforms (e.g., spaceborne and airborne), to detect and map the spectral characteristics of the materials of interest, require spectral libraries as an essential reference. They include field and laboratory spectral information in combination with geochemical analyses for validation. Here, we present a collection of REE- and copper-related hyperspectral spectra with associated geochemical information. The libraries contain reflectance spectra from rare-earth element oxides, REE-bearing minerals, copper-bearing minerals and mine surface samples from the Apliki copper-gold-pyrite mine in the Republic of Cyprus. The samples were measured with the HySpex imaging spectrometers in the visible and near infrared (VNIR) and shortwave infrared (SWIR) range $(400-2500 \mathrm{~nm})$. The geochemical validation of each sample is provided with the reflectance spectra. The spectral libraries are openly available to assist future mineral mapping campaigns and laboratory spectroscopic analyses. The spectral libraries and corresponding geochemistry are published via GFZ Data Services with the following DOIs: https://doi.org/10.5880/GFZ.1.4.2019.004 (13 REE-bearing minerals and 16 oxide powders, Koerting et al., 2019a), https://doi.org/10.5880/GFZ.1.4.2019.003 (20 copper-bearing minerals, Koellner et al., 2019), and https://doi.org/10.5880/GFZ.1.4.2019.005 (37 copper-bearing surface material samples from the Apliki coppergold-pyrite mine in Cyprus, Koerting et al., 2019b). All spectral libraries are united and comparable by the internally consistent method of hyperspectral data acquisition in the laboratory.
\end{abstract}

\section{Introduction}

Reflectance spectroscopy is based on measuring the reflected solar radiation from a material of interest. It uses photosensitive detectors to record and analyze light reflected or scattered from the surface. The spectrum of the reflected light is unique for each material and acts like a spectral fingerprint. Spectral libraries are comprehensive collections representing optical properties of materials in a specific wavelength range. In this data collection, hyperspectral spectra were collected under standardized laboratory or field conditions and include geochemical analyses of the sampled minerals and materials. The geochemical analyses can be used to check and interpret the hyperspectral spectra. Spectral libraries are essential in the field of imaging reflectance spectroscopy for mapping purposes. For example, the spatial distribution of ore-related mineral phases can be mapped by comparing unknown reflectance pixel spectra with known reflectance material spectra from a spectral library. The data that are being analyzed are hyperspectral data cubes that are collected by, e.g., satellite, unmanned aerial vehicle (UAV) or tripod platforms to 
detect and map element or mineral occurrences in natural and in man-made surfaces.

The distinction of different surface materials or minerals is based on the nature of their reflectance spectral characteristics. The recorded reflectance spectral information is a function of the chemical and physical properties of the target material which cause different reactions to the incoming light on a molecular and atomic level (Clark, 1999; Hunt, 1989).

Spectral sensors collect the number of photons that are emitted or reflected per wavelengths by the material in each measured ground pixel. The interaction of the incoming light or radiant flux in a specific wavelength with the matter can reveal important information about the matter itself (Jensen, 2010). This interaction can be the absorption of a photon of a discrete energy state by an isolated atom or ion. This changes the atom's or ion's energy state. During this process energy is emitted that is not equal to the discrete energy of absorption which causes emissions at a different wavelength and creates absorption bands or absorption features (Clark, 1999; Hunt, 1989). The absorption feature position, depth and width depend on the different absorption processes taking place, the kind of chemical bond, the elements involved, and the absorbing ion or molecule and its position in the crystal lattice. Absorption features in the visible and near infrared (VNIR: 400 to $1000 \mathrm{~nm}$ ) and shortwave infrared (SWIR: 1000 to $2500 \mathrm{~nm}$ ) wavelength region are caused by electronic and vibrational processes within the molecule or crystal lattice. The position and cause of these reflectance absorption features are discussed in detail, e.g., in Clark $(1999,2003)$ and Hunt (1989).

Hyperspectral data of geological surfaces can be acquired by ground- or UAV-based outcrop scans to map an ore body's surface mineral distribution by using spectral references libraries. An example of a hyperspectral surface mapping is shown in Fig. 1. Here, the outcrop of former copper-goldpyrite mine Apliki in the Republic of Cyprus was scanned hyperspectrally and mapped utilizing a spectral library of expected surface minerals. The analysis is based on United States Geological Survey (USGS) reflectance spectra. As the USGS spectral library entries do not originate from the same sensor as the mine face scan (HySpex data), they need to be spectrally adapted to the HySpex sensor properties.

In the case of minerals reflectance spectra, only hyperspectral sensors with a spectral bandwidth resolution of approximately $10 \mathrm{~nm}$ or less can capture the fine differences in reflectance at certain wavelength positions (Jensen, 2010). Future hyperspectral imaging satellites will provide the necessary data quality requirements to successfully map rareearth elements (REEs), copper deposits and other resources from space. These satellites will play an important role in the future of geological exploration to help map large mineralized areas in remote regions (Mielke et al., 2016; Swayze et al., 2014). Several global mapping satellite missions will be launched in the next few years. Among them are the German EnMAP, the Chinese CCRSS-A and the Japanese HISUI missions (Guanter et al., 2015; Iwasaki et al., 2011; Tong et al., 2014). For those missions, the imaging spectroscopy community is currently developing methodologies, e.g., for the detection of REEs in the image spectra (Boesche et al., 2015; Boesche et al., 2017; Bösche, 2015; Herrmann, 2019; van der Meer et al., 2012; Turner et al., 2014a,b; Turner, 2015).

We aim to contribute to the already existing, accredited libraries, e.g., the USGS and the ECOSTRESS Spectral Library and various others (Baldridge et al., 2009; Clark et al., 2007; Hunt, 1977; Kokaly et al., 2017; Meerdink et al., 2019; Percival et al., 2016). The available reflectance spectral libraries are commonly based on powdered natural or synthetic samples that are spectrally pure. The spectral data are usually collected by point spectroradiometers, e.g., the Analytical Spectral Devices (ASD) FieldSpec ${ }^{\circledR}$ 3. Our contributed reflectance spectra are based on imaging spectroscopy data from the HySpex classic series scanning samples in a natural and a powdered state. Reflectance spectral libraries like the here presented, based on HySpex imaging data and untreated samples, are not yet freely available for the hyperspectral community.

The spectral and geochemical information of samples presented here belongs to three different mineral assemblages and corresponds to three different types of deposits. The sample's spectral information is provided within four spectral library files and their corresponding geochemical composition files. The four spectral library files represent (1) REE-bearing minerals, (2) synthetic REE oxide powders (Koerting et al., 2019a), (3) copper-bearing minerals (Koellner et al., 2019) and (4) powders of copper-bearing surface material from the Apliki copper-gold-pyrite mine in the Republic of Cyprus (Koerting et al., 2019b). Spectrally, the libraries cover the full wavelength range of the solar optical range (414-2498 nm). The corresponding geochemical analyses are explained in the methods for each sample type. The two REE libraries (Koerting et al., 2019a) consist of the spectra of 16 rare-earth oxide (REO) powders and 13 REE-bearing minerals (REMin). In addition, the spectra of niobium- and tantalum-oxide powders are provided, which will not be mentioned further individually but be included in the term REO. The third spectral library includes 20 copper-bearing minerals (Koellner et al., 2019), and the fourth spectral library contains 37 surface samples from the Apliki copper-gold-pyrite mine site in the Republic of Cyprus (Koerting et al., 2019b). All spectral libraries are united and comparable by the internally consistent method of hyperspectral data acquisition in the laboratory. An extensive list of the samples can be found in the technical reports provided with each dataset.

The samples are presented as reflectance spectral libraries and their geochemical composition. Sample nominations are based on the geological collection of origin or sample abbreviations from the field sampling. The sample nomination is not an interpretation of the presented geochemical data. The datasets are independent of each other, and the reflectance 

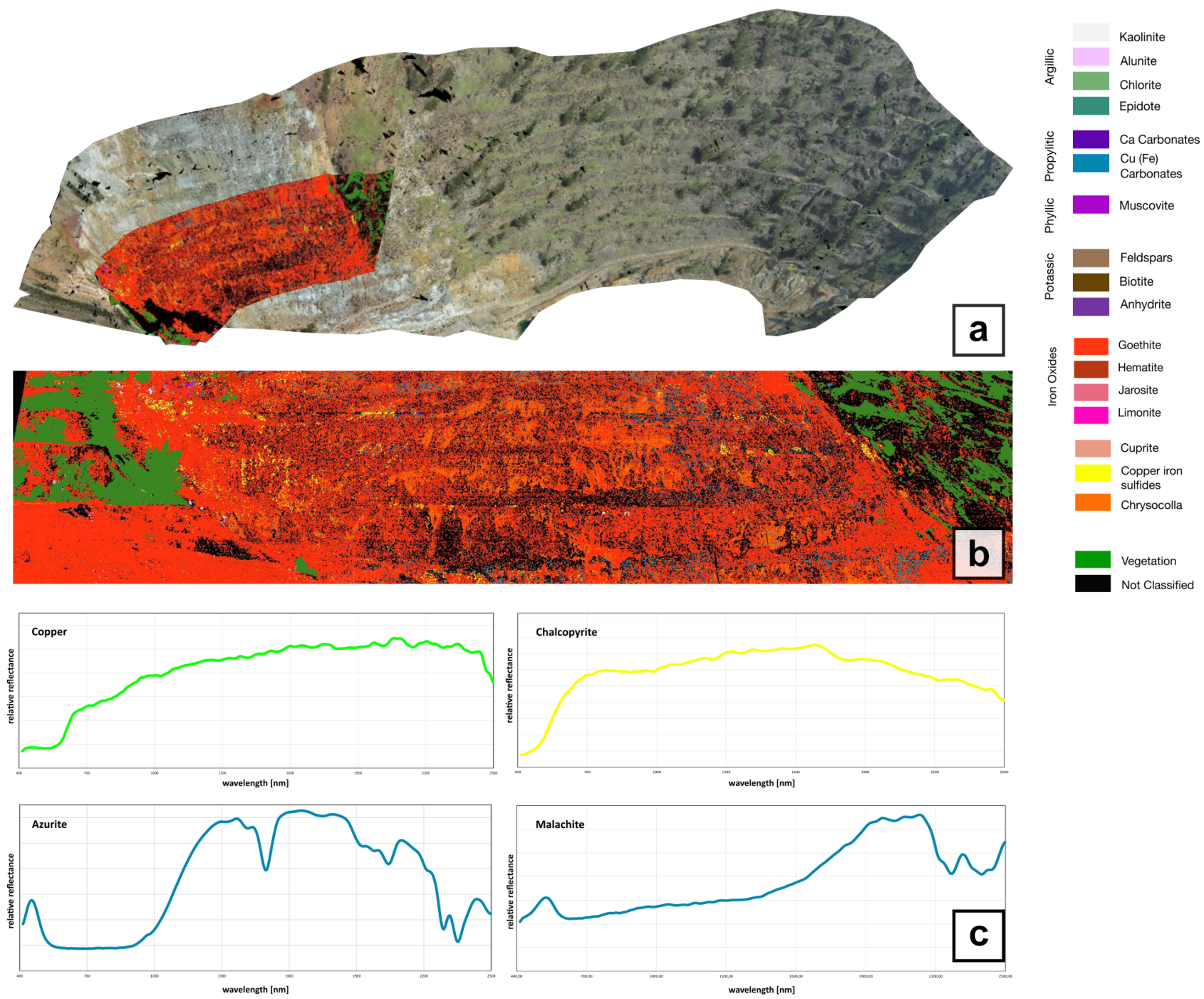

Figure 1. Example for the application of a spectral library. (a) Three-dimensional model of the open-pit Apliki mine in the Republic of Cyprus based on RGB images and a superimposed analysis result of a hyperspectral HySpex scan. The hyperspectral map of the spatial mineral distribution from panel (b) is stacked on the 3D model for visualization purposes. (b) Analysis of a HySpex scan using a custommade spectral library from USGS spectra (Clark et al., 2007). (c) Example of hyperspectral spectra from copper-bearing minerals as presented in Koellner et al. (2019).

spectra can be seen as a spectral expression of the existing geochemical data. Neither the geochemistry nor the reflectance spectra are interpreted or correlated to each other.

The outline of this document follows the necessary line of knowledge to successfully make use of the here presented spectral libraries. Section 2 includes a description of the analyzed materials, and Sect. 3 informs about the methods, including the sample preparation and spectra collection, the hyperspectral data acquisition, covering the processing of the data and spectral measurement parameters, and the geochemical analyses of the samples. Section 4 lists the samples that were measured spectrally and geochemically and the data of which can be accessed via the GFZ Data Services platform. Section 5 discusses the parameters influencing the data. A separate data description and the geochemical analysis results are included as data reports in the three different data publications (Koellner et al., 2019; Koerting et al., 2019a, b).

\section{Materials}

The REE sample material includes 16 REO powders (REO) and 13 REE-bearing minerals (REMin). The REO powders belong to a series of rare-earth metals and compounds $\left(\right.$ REacton $\left.^{\circledR}\right)$ and were purchased from Alfa Aesar. All REO powders contained at least $99.9 \%$ of the REE oxide, as per the seller-supplied concentration certificates. The concentration certificate information can be found in the data description of Koerting et al. (2019a). The REO powders were ob- 
tained as high-purity materials with a grain size of $<63 \mu \mathrm{m}$. The REMin samples (ore minerals) were purchased from Gunnar Färber Minerals, an online trader of mineral specimens. The mineral notation is based on the sample name provided by Gunnar Färber Minerals. The supplier offers analytical services with a modern scanning electron microscopyenergy-dispersive X-ray spectroscopy (SEM-EDX) technology, and therefore we assume the specimens are analyzed and the mineral species is validated before the sale. The $\mathrm{X}$ ray fluorescence (XRF) data presented in the data description of Koerting et al. (2019a) should be consulted to validate the given mineral nomination noted by Gunnar Färber Minerals.

The 20 copper-bearing minerals belong to collections of the University of Potsdam (UP) and the Federal Institute for Geosciences and Natural Resources (BGR); a samples list can be found in Koellner et al. (2019). The minerals were measured hyperspectrally with no sample preparation; the sample photos and geochemical analysis are provided in the data description for Koellner et al. (2019). The 37 Apliki mine surface samples were collected (Koerting et al., 2019b) in March 2018 during a field campaign of the Geological Survey Department of the Republic of Cyprus (GSD) and the GFZ German Research Centre for Geosciences (GFZ). Surface material in the mine was collected and prepared (crushed and pulverized) for the geochemical analysis by Bureau Veritas Minerals (BVM). The powdered samples were measured hyperspectrally as powder tablets; a sample list including photos from the in situ conditions of the samples can be found in the technical report (Koerting et al., 2019b).

\section{Methods}

\subsection{Sample preparation and spectra collection}

The sample preparation varies by sample type and depends on the material and the information of interest. This is based on the research projects that the samples stem from and for which the spectral and geochemical data were acquired.

The reflectance spectra for each sample were manually extracted from the processed hyperspectral image scenes by averaging a number of pixels over a central sample area. The resulting spectra were compiled in a spectral library. Thereby, each reflectance spectrum of a spectral library represents an average reflectance spectrum of the material, depending on the sample size and spectral homogeneity. The extraction of the reflectance spectra is explained in detail in each data description (Koellner et al., 2019; Koerting et al., 2019a, b).

The REO powders were measured in $100 \%$ quartz glass petri dishes underlain by black cellular rubber; each powder was measured separately. Figure 2 shows the measurement setup of holmium-oxide powder as an example for the REO powders. The REE-bearing minerals were measured separately. Figure 3 shows the xenotime sample (brownish single crystal embedded in quartz) as an example for the REMin samples. The REMin samples were measured without sam-

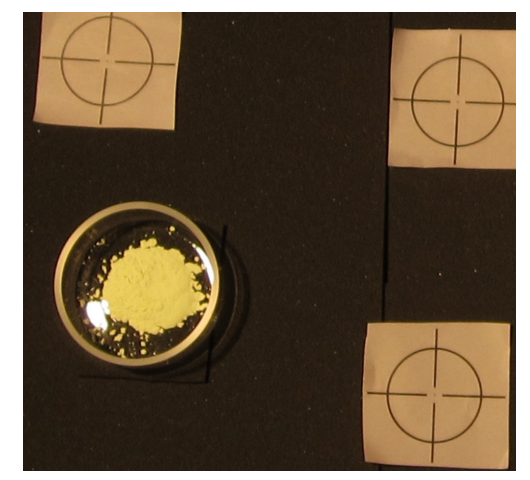

Figure 2. Holmium-oxide powder in the laboratory HySpex setting in a quartz glass petri dish underlain by black cellular rubber. Geometric markers for the pre-processing were placed alongside the sample.

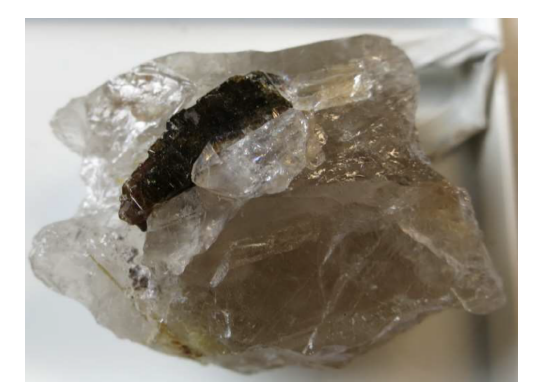

Figure 3. Xenotime embedded in quartz as an example for the REE-bearing mineral samples.

ple preparation on black cellular rubber, as is shown for the copper-bearing minerals in Fig. 4. For all measurements, the final reflectance spectral analyses were spatially reduced to the center pixels of each identified REE-bearing mineral or a 5 pixel $\times 5$ pixel average reflectance spectrum centered on the REO powder sample. Shadow effects from the sidewalls of the boxes could thus be minimized. One representative reflectance spectrum of every REMin and REO sample was collected for the spectral library (Herrmann, 2019).

The copper-bearing mineral samples were measured without any sample preparation as the variable surface of the minerals and the influence of the mineral structure were of interest. Figure 4 shows an example scan of some of the copper-bearing minerals. The full sample list including sample photos and the marked area of the geochemical sampling can be found in the technical report (Koellner et al., 2019). The area used to obtain the spectrum, averaging over a 5 pixel $\times 5$ pixel window, was sampled afterwards for the geochemical analysis.

The Apliki mine samples were crushed and powdered so that $\geq 85 \%$ of the sample was below $75 \mu \mathrm{m}$. Homogenized powders were measured as pressed powder tablets (Fig. 5). The area to obtain the sample's reflectance spectrum was chosen over a 5 pixel $\times 5$ pixel window in the center of the 


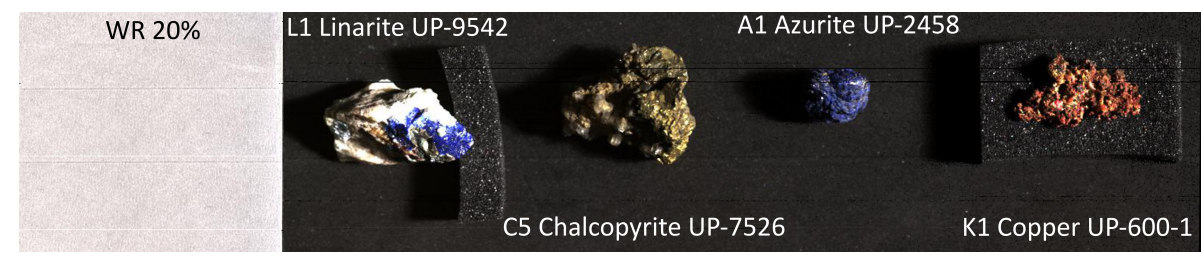

Figure 4. Showing HySpex scan MH_FK_LAB_Cudetect_008_09012018_WR20 as an example to highlight the lack of sample preparation.

powder tablet to minimize influences from the tablet's metal frame. The dark spots in each tablet were caused by previous measurements with a laser-induced breakdown spectrometer (LIBS). The hyperspectral sample spots were chosen in order to exclude the measurement points of the LIBS in the spectral footprint. In the case of broken powder tablets like 7d_Hem, the shadowed, rough surface areas were excluded from the spectral sampling, and an even powder surface was favored.

\subsection{HySpex data recording}

The HySpex VNIR-1600 and SWIR-320m-e (technical description available at http://hyspex.no/products/disc.php, last access: 18 June 2019) are two line-scanning cameras mounted in parallel. They cover the range of the visible to near infrared (VNIR, 414-993 nm) and the shortwave infrared (SWIR, 967-2498 nm) wavelength region. The sensors record an array line of 1600 pixels (VNIR) and 320 pixels (SWIR) (push-broom scanning). Every pixel contains a spectrum with a total spectral sampling number of 408 bands in total.

The HySpex cameras are provided with two acquisition modes: one for airborne data collection and one for laboratory measurements. In laboratory mode, the cameras are combined with a trigger pulse-moving sleigh (translation stage) of a definable frame period (depending on the integration time of every array-line acquisition). The configuration of the translation stage framework, the cameras and the light source (Halogen GX6.35, $2 \times 1000 \mathrm{~W}, 45^{\circ}$ illumination angle) are fixed, while the sleigh and the samples are moving through the focal plane (Rogass et al., 2017).

The reflectance level of a white reference panel, placed in line with the samples, is chosen according to the albedo of the samples. The higher the albedo of the sample, the higher is the diffuse reflectance factor of the white reference panel that is chosen. For the REE samples (REMin and REO), a white reference panel of $95 \%$ reflectance was used because most of the REO samples were bright, white powders of a high albedo; this is based on test measurements of Bösche (2015), Herrmann (2019). The Apliki samples required a $50 \%$ reflectance white reference panel, whereas the copper-bearing minerals were measured using a $20 \%$ reflectance white reference panel. Both the geometrical setup and the heat-up time of the lamp influence the configuration of the light source. The maximum illumination was obtained with an angle of
Table 1. HySpex sensor parameters of the VNIR-1600 (VNIR) and SWIR-320m-e (SWIR).

\begin{tabular}{lll}
\hline \multicolumn{3}{l}{ HySpex sensor parameters } \\
\hline Lamp arrangement & $45^{\circ}$ & \\
& VNIR & SWIR \\
Wavelength range [nm] & $414-993$ & $967-2498$ \\
Pixels per line & 1600 & 320 \\
Sampling interval [nm] & 3.7 & 6 \\
Radiometric resolution & 12 bit & 14 bit \\
Light source & Halogen GX6.35, $2 \times 1000 \mathrm{~W}$ \\
\hline
\end{tabular}

$45^{\circ}$ between the incident light and the vertical plane. The distance between the lamp and the HySpex cameras was higher compared to the distance between the samples and the sensor to ensure diffuse illumination and to avoid thermal influence on the cameras and the samples. The integration time (meaning measurement time for each image line) was tested to be as high as possible to suppress the impact of signal uncorrelated Gaussian white noise and at the same time as low as needed to avoid detector saturation. For all measurements the integration time was chosen with respect to the sample albedo. The HySpex sensor characteristics are listed in Table 1 . The settings used for the REMin and REOs are listed in Table 2, the settings for the copper-bearing minerals in Table 3 and the settings for the Apliki mine samples in Table 4 . The laboratory is equipped with black-painted walls and doors, as well as black curtains to avoid reflected light from surfaces other than the sample; an example setup of the sensors, the translation stage and the samples can be seen in Fig. 6. The laboratory conditions were kept stable, the air temperature was regulated to $21 \pm 0.5^{\circ} \mathrm{C}$ and the humidity was below $70 \%$ for all measurements. Black cellular rubber is used as a base material for all samples for hyperspectral data acquisition. It reflects less than $5 \%$ on average of the incoming radiation.

Detailed descriptions for the GFZ standard measurements and the process chain can be found in Rogass et al. (2017).

\subsection{Hyperspectral data processing}

Each measurement run produces one VNIR and one SWIR 3D data cube. The three dimensions are the two spatial $x$ and $y$ dimensions and the spectral $z$ dimension. The 3D im- 


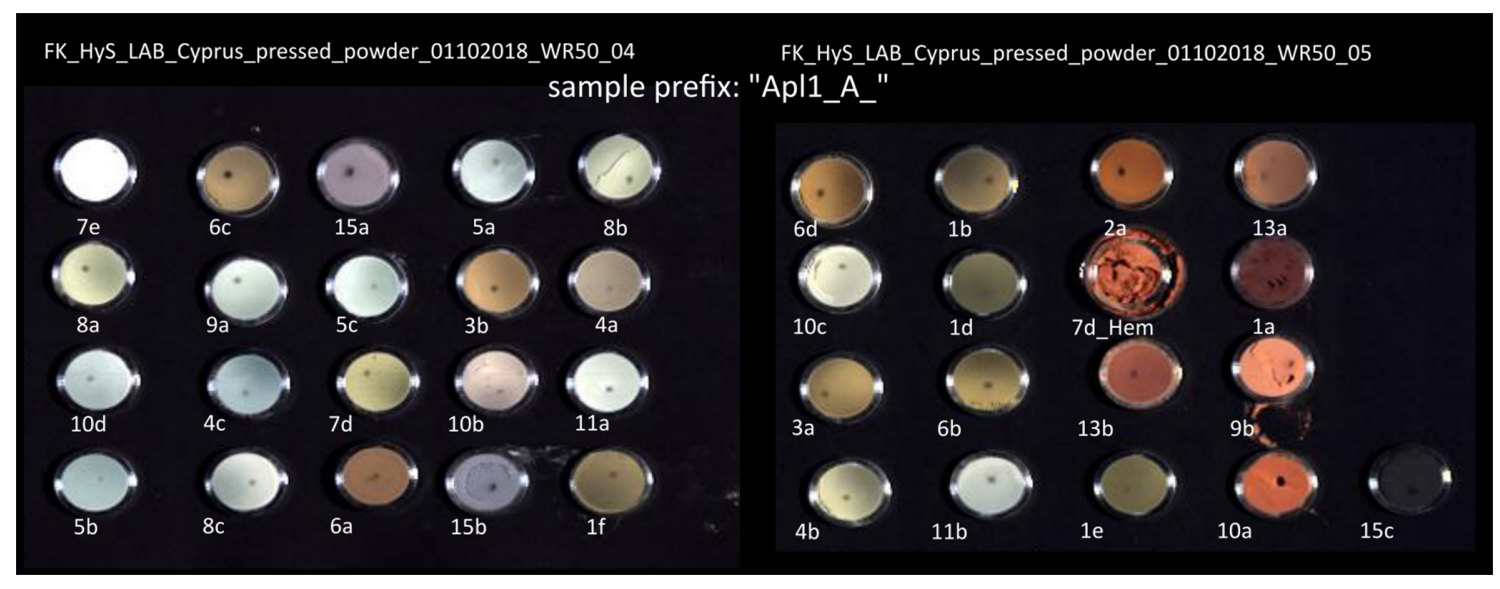

Figure 5. Showing the Apliki mine samples prepared as powder tablets.

Table 2. HySpex settings for laboratory measurements of the REO and REMin (Koerting et al., 2019a, modified following Bösche, 2015; Herrmann, 2019). "eq" stands for CCD equalization filter; "px" stands for pixels.

\begin{tabular}{lll}
\hline HySpex settings & & \\
\hline Distance, sample to sensor & $1 \mathrm{~m}$ & \\
Sensor arrangement head to head & $1 \mathrm{~m}$ lenses, eq on VNIR \\
& VNIR $(1600 \mathrm{px})$ & SWIR $(320 \mathrm{px})$ \\
& 30000 & 5000 \\
Integration time $[\mu \mathrm{s}]$ & 31000 & 123506 \\
Frame period $[\mu \mathrm{s}]$ & & \\
\hline
\end{tabular}

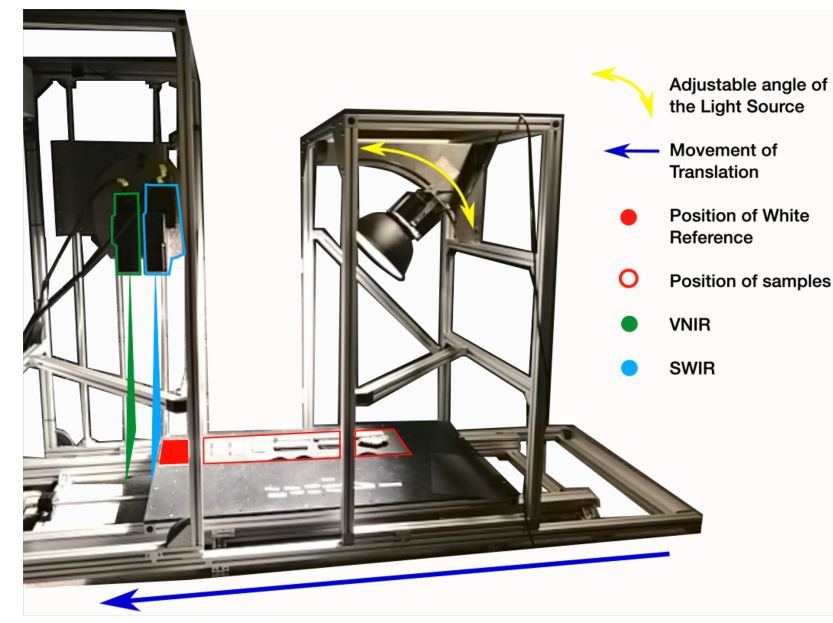

Figure 6. The HySpex translation stage setup (Körting, 2019).

age cubes are produced by moving a homogeneous reflecting white reference panel and the samples through the focal plane of the two sensors. The VNIR image cube is resized to the spatial dimensions of the SWIR data cube, coregistered and stacked with the SWIR data cube, resulting in a continuous image cube with the spectral range of 414$2498 \mathrm{~nm}$. In order to produce a reflectance image, the image pixels that show the white standard were averaged to a one- line reference spectrum. The reflectance was calculated by dividing every image line spectrum by its reference spectrum from the reflecting white reference panel. The resulting reflectance data are scaled from 0-10000. A detailed description for the laboratory setup and processing can be found in Rogass et al. (2017). The software HySpex Ground was used to perform the measurements, and the software HySpex Rad was used to perform the radiometric calibration on the image data.

\subsection{Geochemical sample analysis for sample characterization}

Depending on the sample type, the geochemical analysis methods differ. The methods used for each sample type are listed in Table 5.

\subsubsection{Thermo Niton XL3t (XRF)}

\section{REMin}

The geochemical measurements for the REMin samples were performed using an X-ray fluorescence (XRF) instrument Thermo Niton XL3t (Fisher Scientific, 2002). The XL3t is a lightweight, hand-held XRF analyzer. The measurement principle follows the principle of X-ray fluorescence, where the sample inbound X-rays excite electrons to a higher energy level in the sample material. Energy in the form of XRF 
Table 3. HySpex settings for laboratory measurements of the copper-bearing minerals (Koellner et al., 2019).

\begin{tabular}{lll}
\hline HySpex settings & & \\
\hline Distance, sample to sensor & $30 \mathrm{~cm}$ & \\
Sensor arrangement head to head & $30 \mathrm{~cm}$ lenses, eq on VNIR \\
& VNIR $(1600 \mathrm{px})$ & SWIR $(320 \mathrm{px})$ \\
Integration time $[\mu \mathrm{s}]$ & $120000-140000$ & $15000-20000$ \\
Frame period $[\mu \mathrm{s}]$ & $120062-141004$ & $478334-561768$ \\
\hline
\end{tabular}

Table 4. HySpex settings for laboratory measurements of Apliki mine powdered samples (Koerting et al., 2019b).

\begin{tabular}{lll}
\hline HySpex settings & & \\
\hline Distance, sample to sensor & $1 \mathrm{~m}$ & \\
Sensor arrangement head to head & $1 \mathrm{~m}$ lenses, eq on VNIR \\
& VNIR $(1600 \mathrm{px})$ & SWIR $(320 \mathrm{px})$ \\
& 60000 & 10000 \\
Integration time $[\mu \mathrm{s}]$ & 60060 & 239282 \\
Frame period $[\mu \mathrm{s}]$ & & \\
\hline
\end{tabular}

Table 5. Sample type and corresponding geochemical characterization method.

\begin{tabular}{ll}
\hline Sample type & Geochemical analysis \\
\hline $\begin{array}{l}\text { REO } \\
\text { (Koerting et al., 2019a) }\end{array}$ & Laboratory certificates \\
\hline $\begin{array}{l}\text { REMin } \\
\text { (Koerting et al., 2019a) }\end{array}$ & $\begin{array}{l}\text { X-ray fluorescence (XRF), } \\
\text { electron probe microanalyzer (EPMA) analyses }\end{array}$ \\
\hline $\begin{array}{l}\text { Copper-bearing minerals } \\
\text { (Koellner et al., 2019) }\end{array}$ & Scanning electron microscope (SEM), EPMA \\
\hline $\begin{array}{l}\text { Apliki mine samples } \\
\text { (Koerting et al., 2019b) }\end{array}$ & $\begin{array}{l}\text { Bureau Veritas Mineral analysis, } \\
\text { ICP-MS and ES }\end{array}$ \\
\hline
\end{tabular}

radiation is released when these electrons return to their original state. The frequency of this radiation is characteristic for the measured chemical element, and its intensity is correlated to the concentration level. The intensity of each element is detected as counts per second by the detector, a geometrically optimized large area drift detector (GOLDD). The maximum excitation voltage of the XL3t device is $50 \mathrm{kV}$, which means out of the full REE suite only four light REEs can be detected (lanthanum, cerium, praseodymium and neodymium).

The XL3t spectrometer is attached to a lead-shielded sample chamber, in which samples with a diameter smaller than $3.3 \mathrm{~cm}$ can be placed. Mineral samples can be directly placed in the chamber; powdered samples have to be placed in sample tubes $(2.5 \mathrm{~cm}$ diameter). The sample tubes are made of plastic with a plastic foil on the bottom. The plastic cannot be detected by XRF and therefore does not interfere with the measurements. A built-in camera of the XL3t enables the precise location of the measuring spot. The software used for the measurements is named "NDTr" and the measurement mode was "mining and exploration". The concentration levels are provided along with a balance value. "Balance"
Table 6. Settings used for the Thermo Niton XL3t X-ray fluorescence device (Bösche, 2015).

\begin{tabular}{ll}
\hline \multicolumn{2}{l}{ Thermo Niton XL3t setting } \\
\hline Measurement mode & Test "all geo" \\
Filter & Main, low, high, light \\
Filter measurement time & $30 \mathrm{~s}$ each \\
\hline
\end{tabular}

represents counts per seconds that could not be attributed to one of the measured elements. Table 6 shows the measurement modes and filters used. In-depth description of the XL3t and the XL3t results for each sample can be found in Bösche (2015) and Herrmann (2019). 


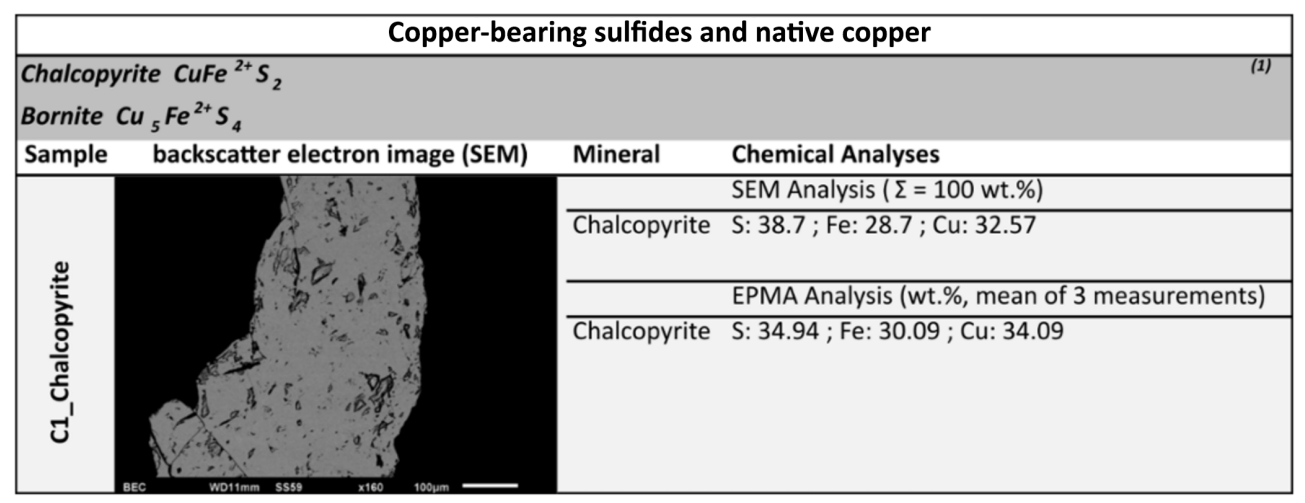

Figure 7. Sample C1_Chalcopyrite SEM and EPMA analysis.

Table 7. Sample C1_Chalcopyrite EPMA analysis results, from three sample points on the sample. Element concentrations reported in wt \% or as below detection limit (bdl).

\begin{tabular}{lllrrrrrr}
\hline Sample point & Al [wt \%] & Hg [wt \%] & Fe [wt\%] & Cu [wt\%] & Si [wt\%] & S [wt\%] & Mn [wt\%] & Total [wt\%] \\
\hline C1_Chalcopyrite-1 & bdl & bdl & 30.00 & 33.98 & bdl & 34.81 & bdl & 98.79 \\
C1_Chalcopyrite-2 & bdl & bdl & 30.19 & 34.108 & bdl & 34.94 & bdl & 99.23 \\
C1_Chalcopyrite-3 & bdl & bdl & 30.08 & 34.194 & bdl & 35.09 & bdl & 99.36 \\
\hline
\end{tabular}

\subsubsection{Scanning electron microscope (SEM) and electron probe microanalyzer (EPMA)}

\section{Copper-bearing minerals}

In order to obtain information about the zonation and internal fabrics of the copper-bearing minerals, a fully automated JEOL JSM-6510 scanning electron microscope (SEM) $(20 \mathrm{kV}$ acceleration voltage) at the University of Potsdam was used. A back-scattered electron detector displays compositional variation in the imaging area based on the mean atomic number of the pixel. An energy dispersive Xray spectrometer (EDX, Oxford Instruments INCAX-act) attached to the instrumentation provides quantitative elemental analysis of single spots. After calibrating with pure copper, a wide spectrum of elements can be identified. Based on previous results, divergences of up to $5 \mathrm{wt} \%$ can be expected, which for quantitative analysis is acceptable.

In order to approximate the values for copper a JEOL JXA-8200 electron probe microanalyzer (EPMA) at the University of Potsdam was used. The electron microprobe is equipped with five wavelength-dispersive X-ray spectrometers (WDX) and was operated with a $20 \mathrm{kV}$ accelerating voltage, a $20 \mathrm{nA}$ current and a beam diameter of $2 \mu \mathrm{m}$. The analytical counting times were $20 / 10 \mathrm{~s}$ for the element peak and $10 / 5 \mathrm{~s}$ for background positions. Analyses were calibrated using silicates/sulfides obtained from the Smithsonian Institution and Astimex. Quantifying elements of a lower atomic mass than boron is not possible; carbon cannot be measured either.
An example SEM analysis for copper-bearing mineral sample C1_Chalcopyrite can be seen in Fig. 7; the EPMA analysis of the mineral is listed in Table 7. The full SEM and EPMA results are documented in Koellner et al. (2019).

\section{REE-bearing minerals}

Some of the REMin (xenotime, bastnaesite, fluorapatite, synchysite and ilmenite) were additionally analyzed by using a JEOL JXA-8200 electron microprobe (EPMA) at the University of Potsdam based on a method developed by Lorenz et al. (2019). The conditions used for the analysis were $20 \mathrm{kV}$ acceleration voltage, $20 \mathrm{nA}$ beam current and a beam size of $2 \mu \mathrm{m}$. Counting times were between $10-20 \mathrm{~s}$ on peak for major elements and $50 \mathrm{~s}$ for REE and other trace elements.

The following spectral lines and mineral standards from Smithsonian and Astimex were used: fluorapatite ( $\mathrm{F} \mathrm{K} \alpha$, $\mathrm{P} \mathrm{K} \alpha, \mathrm{Ca} \mathrm{K} \alpha)$, albite $(\mathrm{Na} \mathrm{K} \alpha)$, fayalite $(\mathrm{Fe} \mathrm{K} \alpha, \mathrm{Mn} \mathrm{K} \alpha)$, wollastonite $(\mathrm{Si} \mathrm{K} \alpha)$, omphacite $(\mathrm{Al} \mathrm{K} \alpha), \mathrm{LaPO}_{4}(\mathrm{La} \mathrm{L} \alpha)$, $\mathrm{PrPO}_{4}(\mathrm{Pr} \mathrm{L} \beta), \mathrm{CePO}_{4}(\mathrm{Ce} \mathrm{L} \alpha), \mathrm{NdPO}_{4}(\mathrm{Nd} \mathrm{L} \beta), \mathrm{YPO}_{4}$ $(\mathrm{Y} \mathrm{L} \alpha), \mathrm{EuPO}_{4}(\mathrm{Eu} \mathrm{L} \alpha), \mathrm{SmPO}_{4}(\mathrm{Sm} \mathrm{L} \beta), \mathrm{LuPO}_{4}(\mathrm{Lu} \mathrm{L} \alpha)$, $\mathrm{GdPO}_{4}(\mathrm{Gd} \mathrm{L} \alpha), \mathrm{ErPO}_{4}(\mathrm{Er} \mathrm{L} \beta), \mathrm{DyPO}_{4}(\mathrm{Dy} \mathrm{L} \beta), \mathrm{YbPO}_{4}$ $(\mathrm{Yb} \mathrm{L} \alpha), \mathrm{HoPO}_{4}(\mathrm{Ho} \mathrm{L} \beta)$, uranothorite $(\mathrm{U} \mathrm{M} \beta)$, and crocoite $(\mathrm{Pb} \mathrm{M} \beta)$. The EPMA data were reduced using the softwareimplemented PRZ-XXP data-correction routine, which is based on the $\varphi(\rho \mathrm{z})$ method (Heinrich and Newbury, 1991).

\subsubsection{Apliki mine surface sample analysis}

The Apliki mine samples were analyzed by Bureau Veritas Minerals' (BVM) Canadian laboratory using their standard 
Table 8. Samples, sample names and locality, and spectral library filenames of REE-bearing minerals.

\begin{tabular}{|c|c|c|c|}
\hline Sample & Original sample name & Sample locality & Spectrum name \\
\hline Aeg & Aegirine, acmite & Rundemyr, Øvre Eiker, Buskerud, Norway/TYP & REMin_Aeg \\
\hline Bar & Bariopyrochlore, fluorapatite & Mina Boa Vista, Catalão, Goiás, Brazil & REMin_Bar \\
\hline Bst & Bastnaesite (Ce) & $\begin{array}{l}\text { Zagi Mountain, Warzal Dam, Peshawar, Khyber Pakhtunkhwa } \\
\text { (formerly North-West Frontier Province), Pakistan }\end{array}$ & REMin_Bst \\
\hline Fap & Fluorapatite, albite & $\begin{array}{l}\text { Golconda Mine, Governador Valadares, Doce Valley, Minas } \\
\text { Gerais, Brazil }\end{array}$ & REMin_Fap \\
\hline Flt & Fluorite & Arbegona, Shashemanne & REMin_Flt \\
\hline Gdl & Gadolinite (Y), synchysite (Y), fluorite & $\begin{array}{l}\text { White Cloud Pegmatite, South Platte, Jefferson County, Col- } \\
\text { orado, USA }\end{array}$ & REMin_Gdl \\
\hline Ilm & Ilmenite & Mogok, Sagaing District, Mandalay, Myanmar & REMin_Ilm \\
\hline Pcr & Polycrase (Y) & $\begin{array}{l}\text { Puoutevare pegmatite, Tjalmijaure Lake, Jokkmokk Lappland, } \\
\text { Northern Sweden }\end{array}$ & REMin_Pcr \\
\hline Prs & Parisite $(\mathrm{Nd})$ including parisite $(\mathrm{Ce})$ & $\begin{array}{l}\text { Mountain Pass Mine, Ivanpah Mountains, San Bernardino } \\
\text { County, California, USA }\end{array}$ & REMin_Prs \\
\hline Syn & Synchysite (Y), microcline, quartz & $\begin{array}{l}\text { White Cloud Pegmatite, South Platte, Jefferson County, Col- } \\
\text { orado, USA }\end{array}$ & REMin_Syn \\
\hline Xtm1 & Xenotime (Y) (a) & Novo Horizonte, Ibitiara, Bahia, Brazil & REMin_Xtm1 \\
\hline $\mathrm{Xtm} 2$ & Xenotime (Y) (b) & Novo Horizonte, Ibitiara, Bahia, Brazil & REMin_Xtm2 \\
\hline Zrn & Zircon & $\begin{array}{l}\text { Peixe Alkaline complex, Monteirópolis, Jaú do Tocantins, To- } \\
\text { cantins, Brazil }\end{array}$ & REMin_Zrn \\
\hline
\end{tabular}

Table 9. Sample name and supplier, product and lot number, and spectral library filenames of the rare-earth oxide powders.

\begin{tabular}{lrrl}
\hline Sample name, supplier & Product number & Lot number & Spectrum name \\
\hline Yttrium (III) oxide, Sigma-Aldrich & 204927 & MKBL2030V & REO_Yttrium \\
Niobium (V) oxide, Alfa Aesar & 11366 & L18Y022 & REO_Niobium \\
Lanthanum (III) oxide, Alfa Aesar & 11272 & B08X015 & REO_Lanthanum \\
Cerium (IV) oxide, Alfa Aesar & 11372 & L07S057 & REO_Cerium \\
Neodymium (III) oxide, Alfa Aesar & 11250 & C02W029 & REO_Neodymium \\
Samarium (III) oxide, Alfa Aesar & 11229 & 61200836 & REO_Samarium \\
Europium (III) oxide, Alfa Aesar & 11299 & A16Z001 & REO_Europium \\
Gadolinium (III) oxide, Alfa Aesar & 11290 & A13W016 & REO_Gadolinium \\
Terbium (III.IV) oxide, Alfa Aesar & 11208 & J24Q019 & REO_Terbium \\
Dysprosium (III) oxide, Alfa Aesar & 11319 & 61300733 & REO_Dysprosium \\
Holmium (III) oxide, Alfa Aesar & 11280 & J11X030 & REO_Holmium \\
Erbium (III) oxide, Alfa Aesar & 11310 & 61000356 & REO_Erbium \\
Thulium (III) oxide, Alfa Aesar & 11198 & F25S060 & REO_Thulium \\
Ytterbium (III) oxide, Alfa Aesar & 11191 & 61201069 & REO_Ytterbium \\
Lutetium (III) oxide, Alfa Aesar & 11255 & G14X082 & REO_Lutetium \\
Tantalum (V) oxide, Alfa Aesar & 14709 & I14Y039 & REO_Tantalum \\
\hline
\end{tabular}




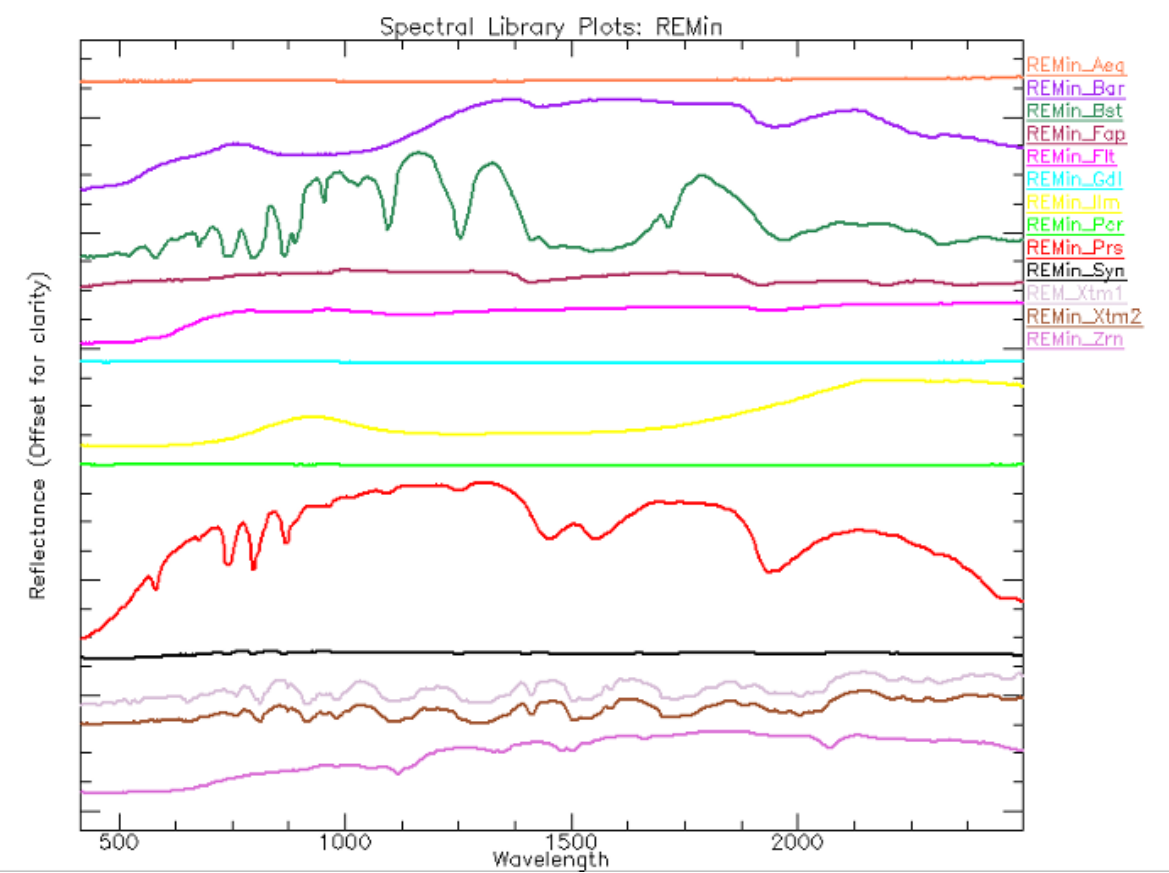

Figure 8. Spectral library plot of the REE -bearing minerals.

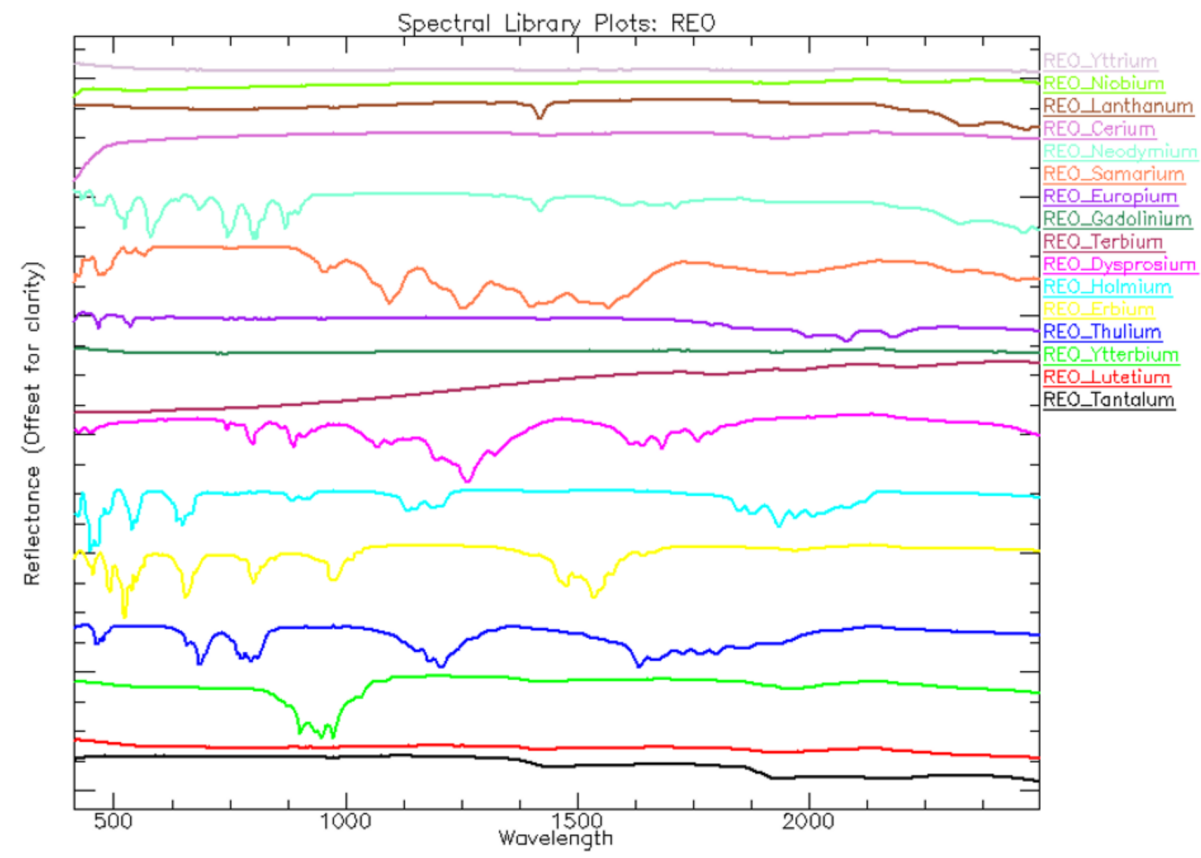

Figure 9. Spectral library plot of the rare-earth oxide powders.

packages (Bureau Veritas, 2020). The samples were pulverized below $75 \mu \mathrm{m}$ and analyzed for major, minor and trace elements using inductively coupled plasma mass spectrometry (ICP-MS) and emission spectrometry (ICP-ES). The results are grouped by the internal BVM sample preparation/analysis method types. Those analysis method types were namely aquatic, rock and soil. The sample numbers, associated analysis method, type and internal BVM analysis codes can be found in the technical report of the Apliki mine surface sample data (Koerting et al., 2019b). 
Table 10. Sample names, collection, original sample name, locality, alteration, mineral formula, spectral library filenames and geochemical composition of the copper-bearing sulfides and native copper.

\begin{tabular}{|c|c|c|c|c|c|c|}
\hline Sample name & Collection & $\begin{array}{l}\text { Original } \\
\text { sample } \\
\text { name }\end{array}$ & Sample locality & $\begin{array}{l}\text { Visible } \\
\text { alteration }\end{array}$ & Spectra names & $\begin{array}{l}\text { Geochemical composition } \\
\text { (EPMA mean, } n=3 \text {, wt } \% \text { ) }\end{array}$ \\
\hline C1_Chalcopyrite & BGR & S55L16 C & $\begin{array}{l}\text { Füsseberg Mine, } \\
\text { Siegerland, } \\
\text { Germany }\end{array}$ & $\begin{array}{l}\text { strongly } \\
\text { altered }\end{array}$ & $\begin{array}{l}\text { C1_Chalcopyrite_BGR- } \\
\text { S55L16-C [5x5 AVG] }\end{array}$ & $\begin{array}{l}\text { S: } 34.941 ; \mathrm{Fe}: 30.091 \text {; } \\
\mathrm{Cu}: 34.094\end{array}$ \\
\hline C2_Chalcopyrite & BGR & S115R12 & $\begin{array}{l}\text { Erzgebirge, } \\
\text { Slovakia }\end{array}$ & $\begin{array}{l}\text { slightly } \\
\text { altered }\end{array}$ & $\begin{array}{l}\text { C2_Chalcopyrite_BGR- } \\
\text { S115R12 [5x5 AVG] }\end{array}$ & $\begin{array}{l}\text { S: } 34.903 \text {; Fe: } 30.068 \text {; } \\
\text { Cu: } 33.95\end{array}$ \\
\hline C3_Chalcopyrite & BGR & S131L5 C & $\begin{array}{l}\text { Henderson Mine, } \\
\text { Clear Creek } \\
\text { County, USA }\end{array}$ & tarnished & $\begin{array}{l}\text { C3_Chalcopyrite_BGR- } \\
\text { S131L5-C [5x5 AVG] }\end{array}$ & $\begin{array}{l}\text { S: } 35.039 ; \text { Fe: 30.106; } \\
\mathrm{Cu}: 33.965\end{array}$ \\
\hline C4_Chalcopyrite & UP & 7534 & $\begin{array}{l}\text { Cornwall, England, } \\
\text { GB }\end{array}$ & $\begin{array}{l}\text { slightly } \\
\text { altered }\end{array}$ & $\begin{array}{l}\text { C4_Chalcopyrite_UP-7534 } \\
\text { [5x5 AVG] }\end{array}$ & $\begin{array}{l}\text { S: } 35.007 ; \text { Fe: } 30.156 ; \\
\text { Cu: } 34.044\end{array}$ \\
\hline C5_Chalcopyrite & UP & 7526 & $\begin{array}{l}\text { Clausthal, Harz, } \\
\text { Germany }\end{array}$ & altered & $\begin{array}{l}\text { C5_Chalcopyrite_UP-7526 } \\
\text { [5x5 AVG] }\end{array}$ & $\begin{array}{l}\text { S: } 35.053 ; \text { Fe: } 30.007 ; \\
\text { Cu: } 34.177\end{array}$ \\
\hline K1_Copper & UP & $600-1$ & $\begin{array}{l}\text { Furnace, Lübeck, } \\
\text { Germany }\end{array}$ & $\begin{array}{l}\text { slightly } \\
\text { altered }\end{array}$ & $\begin{array}{l}\text { K1_Copper_UP-600-1 } \\
\text { [5x5 AVG] }\end{array}$ & $\mathrm{Cu}: 98.577$ \\
\hline
\end{tabular}

\section{Results}

All samples are provided and described in detail in the corresponding technical reports that are available upon download of the datasets. For clarity purposes, all provided samples and corresponding spectra names are listed in Tables 8-12, including a short sample description and, where applicable, the sampling location, geochemistry or mineralogy. For each file collection a plot of the spectral library is shown (Figs. 813).

\subsection{REE-bearing minerals and rare-earth oxide powders}

The REE-bearing minerals are listed in Table 8. Figure 8 shows a plot of the corresponding spectral library. Table 9 lists the rare-earth oxide powders, and Fig. 9 shows the plot of the spectral library.

\subsection{Copper-bearing minerals}

The copper-bearing minerals are listed in Tables 10 (copperbearing sulfides and native copper) and 11 (copper-bearing silicates, carbonates and sulfates). The plots of the corresponding spectral libraries are shown in Fig. 10 (copperbearing sulfides and native copper) and 11 (copper-bearing silicates, carbonates and sulfates).

\subsection{Apliki mine samples}

The Apliki mine samples are listed in Table 12, and the plots of the corresponding spectral library are shown in Figs. 12 and 13 .

\section{Data availability}

The spectral libraries are published under the Creative Commons Attribution International 4.0 License (CC BY 4.0) via GFZ Data Services. Due to the different types of samples, we present the following three data publications: (1) Mineral reflectance of 29 rare-earth minerals and rare-earth oxide powders including niobiumand tantalum-oxide powder, V. 2.0 GFZ Data Services, https://doi.org/10.5880/GFZ.1.4.2019.004 (Koerting et al., 2019a); (2) Mineral reflectance spectra and chemistry of 20 copper-bearing minerals, V. 2.0 GFZ Data Services, https://doi.org/10.5880/GFZ.1.4.2019.003 (Koellner et al., 2019) and (3) Mineral reflectance spectra and chemistry of 37 copper-bearing surface samples from Apliki coppergold-pyrite mine in the Republic of Cyprus, V. 2.0 GFZ Data Services, https://doi.org/10.5880/GFZ.1.4.2019.005 (Koerting et al., 2019b).

\section{Validation and discussion}

Technical validation of the results in terms of sample material properties, systematic errors and variation of measurements (experimental error) are given below.

\subsection{Sample material properties}

The REO powders were certified to contain at least $99.9 \%$ of the corresponding REO. The certificates are listed in Koerting et al. (2019a). The REE mineral samples were geochemically analyzed using the Thermo Niton XL3t (Fisher Scientific, 2002) device. The resulting element concentrations and 
Table 11. Sample names, collection, original sample name, locality, alteration, mineral formula, spectral library filenames and geochemical composition of the copper-bearing silicates, carbonates and sulfates.

\begin{tabular}{|c|c|c|c|c|c|c|}
\hline Sample name & Collection & $\begin{array}{l}\text { Original } \\
\text { sample } \\
\text { name }\end{array}$ & Sample locality & $\begin{array}{l}\text { Visible } \\
\text { alteration }\end{array}$ & Spectra name & $\begin{array}{l}\text { Geochemical composition } \\
\text { (EPMA mean, } n=3 \text {, wt } \%)\end{array}$ \\
\hline A1_Azurite & UP & 2458 & $\begin{array}{l}\text { Chéroy near Lyon, } \\
\text { France }\end{array}$ & altered, nodular & $\begin{array}{l}\text { A1_Azurite_UP-2458 } \\
{[5 \times 5 \text { AVG] }}\end{array}$ & $\mathrm{CuO}: 65.344 ; \mathrm{HgO}: 0.091$ \\
\hline A2_Azurite & UP & 2437 & $\begin{array}{l}\text { Tsumeb near Otavi, } \\
\text { Namibia }\end{array}$ & altered & $\begin{array}{l}\text { A2_Azurite_UP-2437 } \\
{[5 \times 5 \text { AVG] }}\end{array}$ & CuO: 65.194 \\
\hline A3_Azurite & BGR & S101L7 & $\begin{array}{l}\text { Cornberg by Fulda, } \\
\text { Germany }\end{array}$ & strongly altered & $\begin{array}{l}\text { A3_Azurite_BGR-S101L7 } \\
{[5 \times 5 \text { AVG] }}\end{array}$ & $\begin{array}{l}\mathrm{CuO}: 63.87 ; \mathrm{SO}_{3}: 0.127 \\
\mathrm{FeO}: 0.179\end{array}$ \\
\hline B1_Brochantite & BGR & S115R3 & Altenberg, Slovakia & $\begin{array}{l}\text { slightly altered, } \\
\text { powdered }\end{array}$ & $\begin{array}{l}\text { B1_Brochantite_BGR-S115R3 } \\
\text { [5x5 AVG] }\end{array}$ & $\begin{array}{l}\mathrm{Al}_{2} \mathrm{O}_{3}: 0.18 ; \mathrm{SiO}_{2}: 0.069 \\
\mathrm{SO}_{3}: 16.262 ; \mathrm{CuO}: 80.334\end{array}$ \\
\hline F1_Unknown & BGR & S115R14 & $\begin{array}{l}\text { Kotterbach near } \\
\text { Witków, Poland }\end{array}$ & slightly altered & $\begin{array}{l}\text { F1_Unknown_BGR-S115R14 } \\
\text { [5x5 AVG] }\end{array}$ & $\begin{array}{l}\mathrm{SiO}_{2}: 2.588 ; \mathrm{FeO}: 69.042 \\
\mathrm{CuO}: 0.25 ; \mathrm{SO}_{3}: 0.161 \\
\mathrm{MnO} 0.292\end{array}$ \\
\hline L1_Linarite & UP & 9542 & Unknown location & $\begin{array}{l}\text { slightly altered, } \\
\text { acicular }\end{array}$ & $\begin{array}{l}\text { L1_Linarite_UP-9542 } \\
{[5 \times 5 \text { AVG] }}\end{array}$ & $\begin{array}{l}\mathrm{SO}_{3}: 64.18 ; \mathrm{CuO}: 24.184 ; \\
\mathrm{HgO}: 0.439\end{array}$ \\
\hline M1_Malachite & BGR & S134R8 & $\begin{array}{l}\text { L'Etoile du Congo } \\
\text { Mine, Katanga, } \\
\text { Congo }\end{array}$ & altered, nodular & $\begin{array}{l}\text { M1_Malachite_BGR-S134R8 } \\
\text { [5x5 AVG] }\end{array}$ & CuO: 67.609 \\
\hline M2_Malachite & BGR & S131L5 M & $\begin{array}{l}\text { Henderson Mine, } \\
\text { Clear Creek } \\
\text { County, USA }\end{array}$ & strongly altered & $\begin{array}{l}\text { M2_Malachite_BGR-S131L5-M } \\
\text { [5x5 AVG] }\end{array}$ & CuO: 66.917 \\
\hline M3_Malachite & BGR & S131R4 & $\begin{array}{l}\text { Tsumeb near Otavi, } \\
\text { Namibia }\end{array}$ & altered & $\begin{array}{l}\text { M3_Malachite_BGR-S131R4 } \\
\text { [5x5 AVG] }\end{array}$ & $\mathrm{CuO}: 65.176 ; \mathrm{SO}_{3}: 0.458$ \\
\hline M4_Malachite & BGR & S132L2 & $\begin{array}{l}\text { Ogonja Mine } \\
\text { in Okahandja, } \\
\text { Namibia }\end{array}$ & strongly altered & $\begin{array}{l}\text { M4_Malachite_BGR-S132L2 } \\
\text { [5x5 AVG] }\end{array}$ & CuO: 67.051 \\
\hline M5_Malachite & BGR & S55L16 M & Siegen, Germany & $\begin{array}{l}\text { slightly altered, } \\
\text { acicular }\end{array}$ & $\begin{array}{l}\text { M5_Malachite_BGR-S55L16-M } \\
\text { [5x5 AVG] }\end{array}$ & CuO: 67.885 \\
\hline P1_Plancheite & UP & Oberhä & Jordan & slightly altered & $\begin{array}{l}\text { P1_Plancheite_UP-Oberhä } \\
\text { [5x5 AVG] }\end{array}$ & $\begin{array}{l}\mathrm{Al}_{2} \mathrm{O}_{3}: 2.951 ; \mathrm{SiO}_{2}: 42.079 \\
\mathrm{CuO}: 51.782 ; \mathrm{SO}_{3}: 0.061 ; \\
\text { MnO: } 0.243\end{array}$ \\
\hline P2_Plancheite & UP & Oberhä2 & Jordan & slightly altered & $\begin{array}{l}\text { P2_Plancheite_UP-Oberhä2 } \\
\text { [5x5 AVG] }\end{array}$ & $\begin{array}{l}\mathrm{Al}_{2} \mathrm{O}_{3}: 3.727 ; \mathrm{SiO}_{2}: 44.12 \\
\mathrm{CuO}: 48.902 ; \mathrm{SO}_{3}: 0.282 \\
\mathrm{MnO}: 0,247\end{array}$ \\
\hline P3_Plancheite & UP & Oberhä3 & Jordan & slightly altered & $\begin{array}{l}\text { P3_Plancheite_UP-Oberhä3 } \\
\text { [5x5 AVG] }\end{array}$ & $\begin{array}{l}\mathrm{Al}_{2} \mathrm{O}_{3}: 2.74 ; \mathrm{SiO}_{2}: 43.25 \\
\mathrm{CuO}: 51.37 ; \mathrm{SO}_{3}: 0.266 \\
\text { MnO: } 0.085\end{array}$ \\
\hline
\end{tabular}

the measurement error $(2 \sigma)$ are provided in Koerting et al. (2019a). The validation for the copper-bearing minerals can be found in Koellner et al. (2019), and the Apliki mine sample validation, analyzed by BVM, can be found in Koerting et al. (2019b).

\subsection{Systematic errors of hyperspectral data acquisition}

Systematic errors are discussed based on instrument drift, calibration and optimization of measurements. Initializing a warm-up phase of optical components, detectors and lamps reduced influences due to instrument drift. Additionally, laboratory conditions were monitored to ensure a stable temperature and humidity. The HySpex cameras and the reference standards are factory calibrated once per year. Measurements used for the final reflectance spectral library were collected within one calibration time span to ensure equal acquisition conditions. For HySpex, averaging multiple measurements minimizes variations in the data. An average (median) of 500 to 800 pixel reflectance spectrum was taken for the HySpex REE and REO reflectance spectra. This number relates to the maximum number of non-disturbed pixels per sample region of interest (e.g., pixels that were not shadowed from the sample holder side walls). For the copper-bearing minerals and the Apliki mine powders, a $5 \times 5$ average pixel window was chosen over the area of interest. For these samples using a smaller pixel number for the average was necessary, as the sampling of the copper-bearing minerals for geochemical 


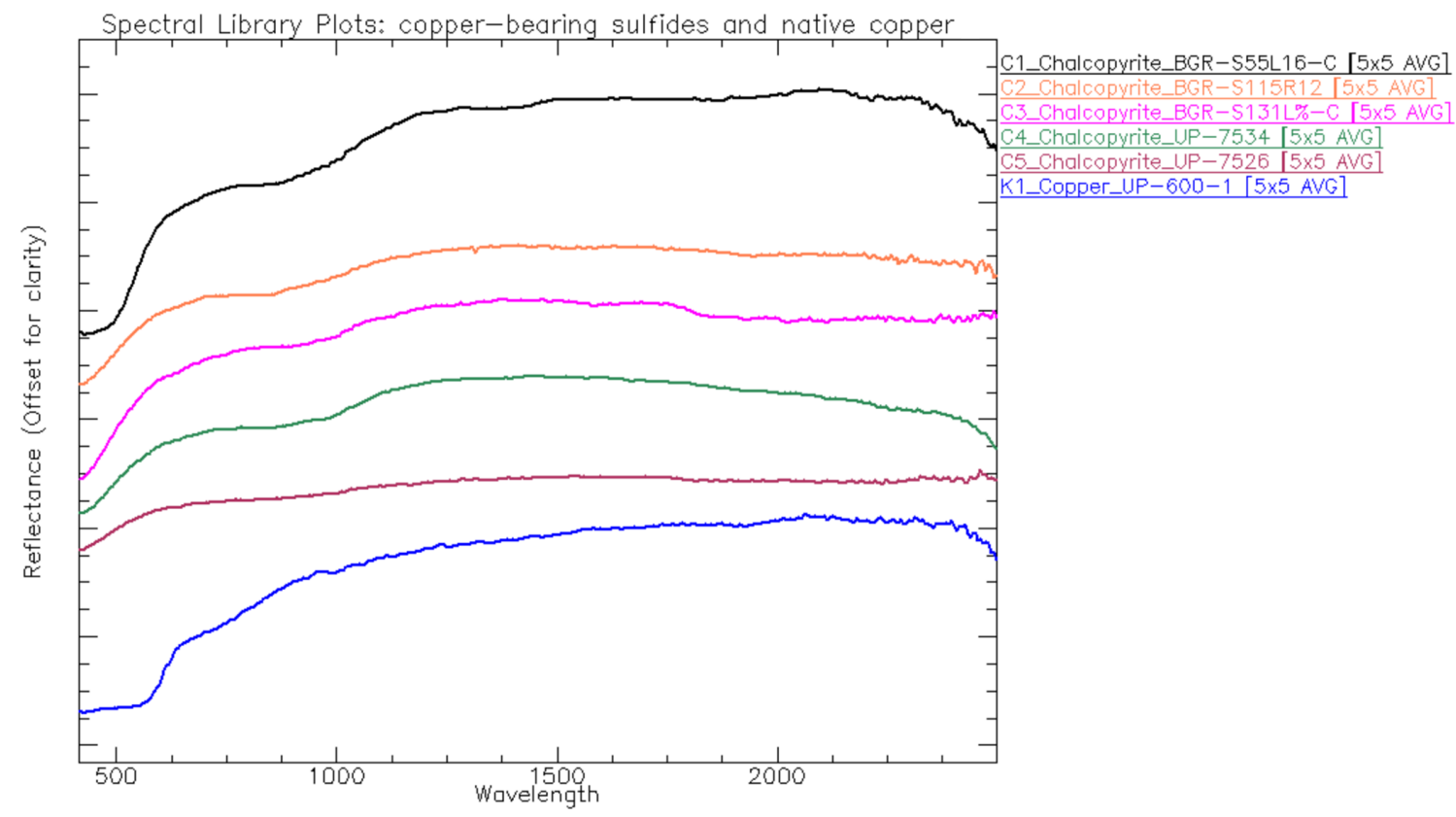

Figure 10. Spectral library plot of the copper-bearing sulfides and native copper.

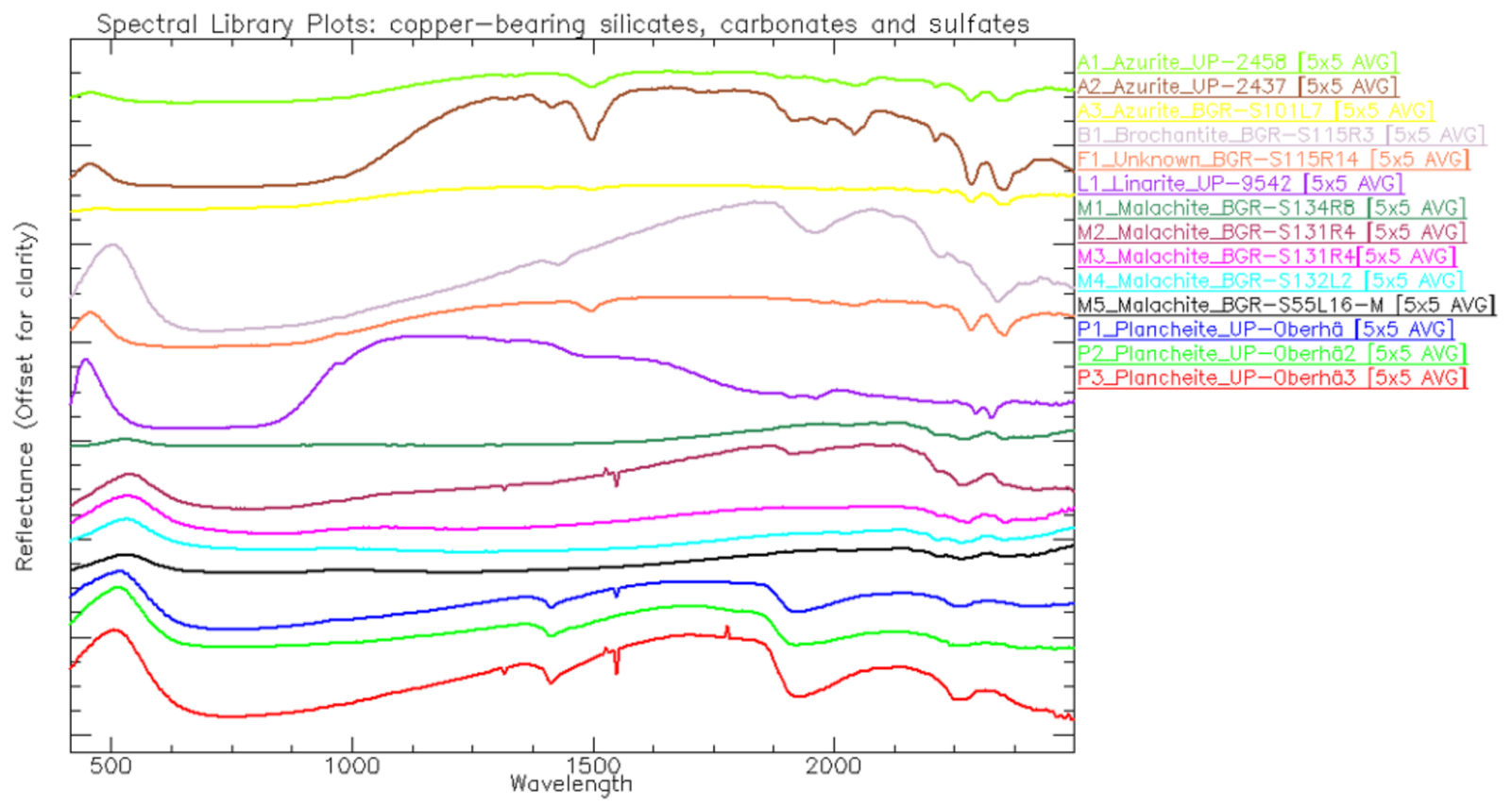

Figure 11. Spectral library plot of the copper-bearing minerals - silicates, carbonates and sulfates.

validation occurred over a small area of the sample, and the Apliki mine powder tablets were too small to ensure a larger homogenous area.

\subsection{Measurements variation}

Variations of measurements were not only based on instrument calibrations or drift. They can also occur due to the detector geometry or geochemical properties of the minerals. These variations may appear as a shift of the peak positions of the absorption bands. This means that different hyperspectral sensors will show variations in the spectrum of the same 
Table 12. Sample names, spectral library filenames, description and mineralogy of Apliki mine sample collection.

\begin{tabular}{|c|c|c|}
\hline "spectra name" & Description & $\begin{array}{l}\text { Mineralogy based on qualitative XRD analysis (in no particular } \\
\text { order) from Koerting (2021) }\end{array}$ \\
\hline Apl1_A_1a, "Apl1_A_1a[5x5 AVG]" & Grey-green fresh surface & Not available \\
\hline Apl1_A_1b, “Apl1_A_1b [5x5 AVG]" & Hematite colored weathering crust & Andesine (anorthic), quartz, magnetite, montmorillonite \\
\hline Apl1_A_1d, "Apl1_A_1d [5x5 AVG]" & Fresh, dark-green weathering crust & Anorthite, magnetite, diopside, quartz, montmorillonite \\
\hline Apl1_A_1e, “Apl1_A_1e [5x5 AVG]" & Yellowish orange weathering crust & Magnetite, quartz, montmorillonite, diopside, anorthite \\
\hline Apl1_A_1f, “Apl1_A_1f [5x5 AVG]" & Soil formation, gravel & Magnetite, anorthite, quartz, montmorillonite, pyrite \\
\hline Apl1_A_2a, “Apl1_A_2a[5x5 AVG]" & Waste, soil & $\begin{array}{l}\text { Goethite, quartz, clinochlore, jarosite-natrojarosite, Andesine, } \\
\text { gypsum }\end{array}$ \\
\hline Apl1_A_3a, "Apl1_A_3a [5x5 AVG]" & Yellowish weathered, soil & $\begin{array}{l}\text { Andesine (anorthic), quartz, gypsum, clinochlore, jarosite, } \\
\text { montmorillonite }\end{array}$ \\
\hline Apl1_A_3b, Apl1_A_3b [5x5 AVG] & Brownish weathered, soil & $\begin{array}{l}\text { Quartz, andesine, clinochlore, gypsum, jarosite, montmoril- } \\
\text { lonite }\end{array}$ \\
\hline Apl1_A_4a, "Apl1_A_4a [5x5 AVG]" & White, small-grained gravel & Gypsum, quartz, clinochlore, rozenite \\
\hline Apl1_A_4b, “Apl1_A_4b [5x5 AVG]" & Grey, small-grained gravel & Quartz, clinochlore, andesine, gypsum, montmorillonite \\
\hline Apl1_A_4c, “Apl1_A_4c [5x5 AVG]" & Grey-green weathering crust & Quartz, clinochlore \\
\hline Apl1_A_5a, “Apl1_A_5a[5x5 AVG]” & Medium-grey weathering crust & Gypsum, quartz, clinochlore \\
\hline Apl1_A_5b, “Ap11_A_15b [5x5 AVG]" & Dark-grey weathering crust & Gypsum, quartz, clinochlore \\
\hline Apl1_A_5c, "Apl1_A_5c [5x5 AVG]" & Light-grey weathering crust & Quartz, gypsum, clinochlore, goethite, hexahydrite \\
\hline Apl1_A_6a, "Apl1_A_6a [5x5 AVG]" & Reddish brown, soil, gravel & $\begin{array}{l}\text { Quartz, pyrite, analcime, goethite, montmorillonite, } \\
\text { clinochlore, anorthite }\end{array}$ \\
\hline Apl1_A_6b, “Apl1_A_6b [5x5 AVG]" & Reddish brown, soil & $\begin{array}{l}\text { Anorthite, quartz, magnetite, diopside, montmorillonite, gyp- } \\
\text { sum, goethite }\end{array}$ \\
\hline Apl1_A_6c, "Apl1_A_6c [5x5 AVG]" & Reddish brown & $\begin{array}{l}\text { Quartz, clinochlore, analcime, gypsum, calcite, jarosite, pyrite, } \\
\text { montmorillonite }\end{array}$ \\
\hline Apl1_A_6d, "Apl1_A_6d [5x5 AVG]" & Reddish brown, soil & $\begin{array}{l}\text { Quartz, pyrite, anorthite, analcime, clinochlore, montmoril- } \\
\text { lonite }\end{array}$ \\
\hline Apl1_A_7d, "Apl1_A_7d [5x5 AVG]" & Grey, crust unstable & Quartz, hexahydrite, clinochlore, gypsum, pyrite \\
\hline Apl1_A_7d_Hem, “Apl1_A_7d_Hem [5x5 AVG]" & Red, hematite & Pyrite, hematite, quartz, gypsum, clinochlore \\
\hline Apl1_A_7e, "Apl1_A_7e [5x5 AVG]" & Blue crystal & Rozenite, goethite, quartz, apjohnite, ferrohexahydrite \\
\hline Apl1_A_8a, "Apl1_A_8a [5x5 AVG]" & Grey, small-grained gravel & Quartz, clinochlore, pyrite, ajoite \\
\hline Apl1_A_8b, “Apl1_A_8b [5x5 AVG]" & Grey, small-grained gravel & Quartz, clinochlore, pyrite, ajoite \\
\hline Apl1_A_8c, "Apl1_A_8c [5x5 AVG]" & Grey, soilish, & Quartz, clinochlore, pyrite, ajoite \\
\hline Apl1_A_9a, "Apl1_A_9a [5x5 AVG]" & Light-green weathering crust & Quartz, clinochlore (Mn), clinochlore \\
\hline Apl1_A_9b, "Apl1_A_9b [5x5 AVG]" & Hematite vein & Quartz, clinochlore, pyrite, hematite \\
\hline Apl1_A_10a, "Apl1_A_10a [5x5 AVG]" & White-with-pink weathering crust & Clinochlore, hematite, quartz \\
\hline Apl1_A_10b, "Apl1_A_10b [5x5 AVG]" & White-with-purple weathering crust & Quartz, clinochlore \\
\hline Apl1_A_10c, “Apl1_A_10c [5x5 AVG]” & Greenish veins & Quartz, clinochlore \\
\hline Apl1_A_10d, “Ap11_A_10d [5x5 AVG]” & White evaporitic crust & Quartz, clinochlore, pyrite \\
\hline Apl1_A_11a, "Ap11_A_11a [5x5 AVG]" & Grey weathering crust & Quartz, clinochlore, gypsum, bassanite \\
\hline Apl1_A_11b, "Apl1_A_11b [5x5 AVG]" & Green weathering crust & Quartz, clinochlore, sphalerite \\
\hline Apl1_A_13a, "Apl1_A_13a [5x5 AVG]" & Red, rock & $\begin{array}{l}\text { Andesine, quartz, magnetite, montmorillonite- } \\
\text { chlorite, diopside }\end{array}$ \\
\hline Apl1_A_13b, “Ap11_A_13b [5x5 AVG]" & Red, gravel, weathered hillside rock & Clinochlore, quartz, montmorillonite \\
\hline Apl1_A_15a, "Apl1_A_15a [5x5 AVG]" & Dark-blue crystalline crust & $\begin{array}{l}\text { Quartz ( } 82.6 \%) \text {, Pyrite }(7.5 \%) \text {, Chalcopyrite }(0.8 \%) \text {, pentahy- } \\
\text { drate (cuprian) }(9.1 \%)\end{array}$ \\
\hline Apl1_A_15b, “Apl1_A_15b [5x5 AVG]" & Light-blue rock and blue crust & $\begin{array}{l}\text { Quartz }(86.1 \%) \text {, pyrite }(4.5 \%) \text {, pentahydrate (cuprian) }(7.1 \%) \text {, } \\
\text { covellite }(2.4 \%)\end{array}$ \\
\hline Apl1_A_15c, "Apl1_A_15c [5x5 AVG]" & Black pyrite & $\begin{array}{l}\text { Covellite }(18.9 \%) \text {, quartz }(39.9 \%) \text {, chalcanthite }(21.8 \%) \text {, } \\
\text { pyrite }(20.0 \%)\end{array}$ \\
\hline
\end{tabular}




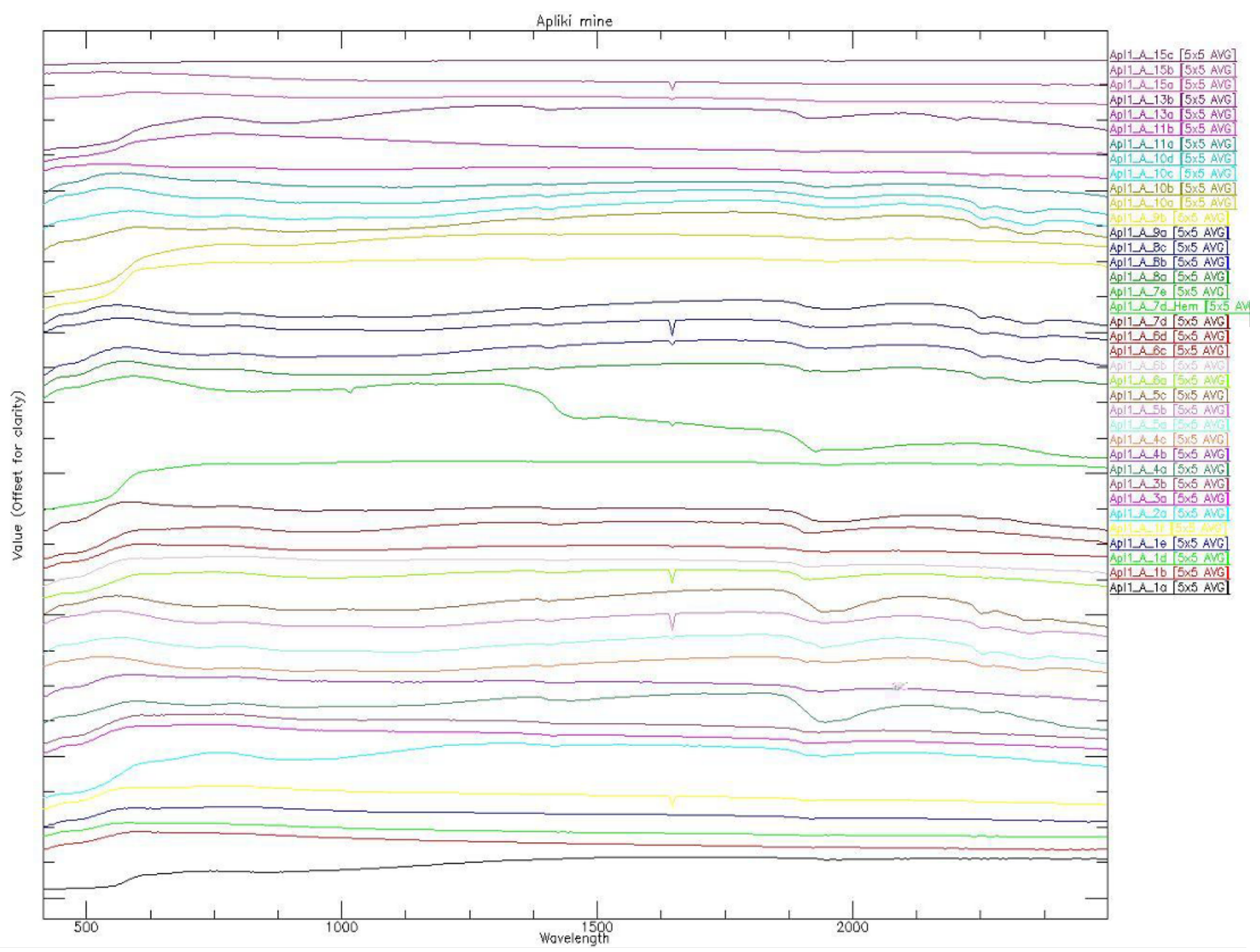

Figure 12. Spectral library of the 37 different Apliki mine samples; spectra stacked with offset.

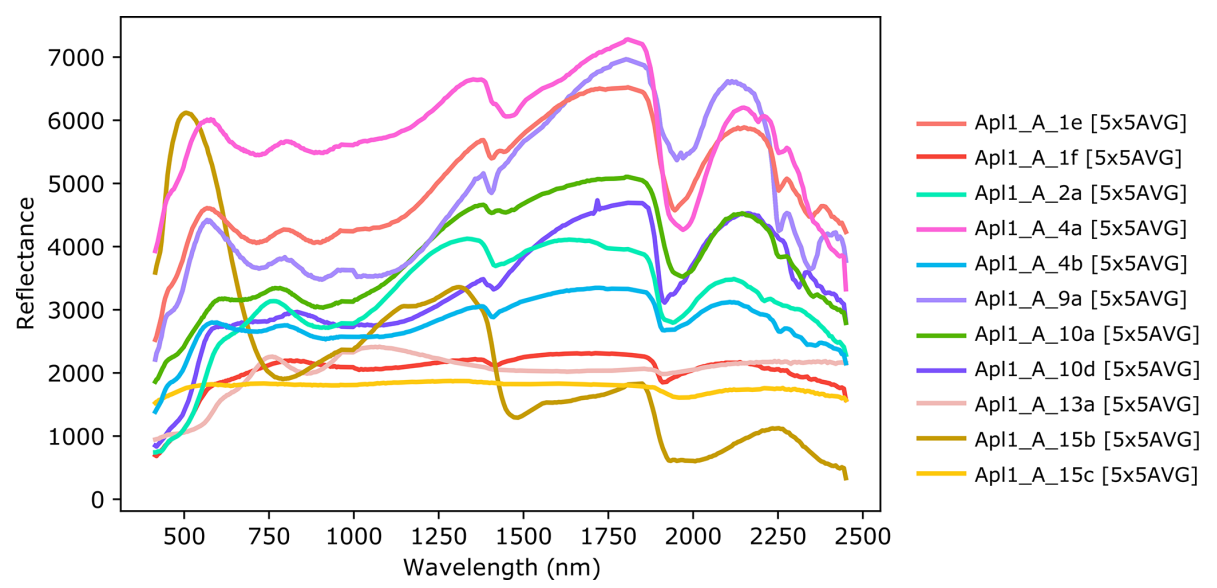

Figure 13. Detailed, unstacked view of a selection of spectra. Reflectance scaled from 0-10000, modified from Koerting (2021).

material. By only using one set of hyperspectral sensors, the HySpex VNIR and SWIR, these shifts will not appear in our data sets. They might show when comparing our reflectance spectra of a material with reflectance spectra taken from a different instrument. For the copper-bearing minerals, the sample reflectance spectra also differ when comparing different samples of the same mineral species (e.g., malachite) to each other. The spectral signal differs, for example, due to changes in geochemistry and physical appearance, e.g., crystallization and degree of weathering (Clark, 1999; Hunt, 
1989; Hunt and Ashley, 1979). To avoid measurement variations caused by different sensors, imaging data from the same sensors as the spectral library should to be used for the analysis. An example for an application can be using the here provided spectral library of the Apliki mine samples for an analysis of the HySpex hyperspectral imaging data of the Apliki mine face to be published in 2021 (Koerting et al., 2021).

\subsection{XL3t systematic errors}

The XL3t is internally calibrated and provides an internal warm-up phase to guarantee stable measurement conditions. Unlike the spectrometer measurements, experimental error was only provided for the XL3t. In order to reduce the experimental error, a long duration measurement time of $120 \mathrm{~s}$ was set. The XL3t collects the emitted radiation from the sample using four different filters. While the sample was irradiated, each filter measures counts per second within a time span of $30 \mathrm{~s}$. Next, the average counts per second were internally transformed to parts per million. The irradiation of, in total, 120 s per sample was empirically tested to enable short measurement duration in combination with the lowest achievable standard deviation of concentration level. 


\section{Appendix A}

Table A1. List of less commonly known terms and their abbreviations used throughout the paper.

\begin{tabular}{|c|c|c|}
\hline Terms & Abbreviation & Description \\
\hline \multirow[t]{9}{*}{ Abbreviation } & REE & Rare-earth element \\
\hline & REO & Rare-earth oxide \\
\hline & REMin & Rare-earth element-bearing mineral \\
\hline & VNIR & Visible light and near infrared \\
\hline & SWIR & Shortwave infrared \\
\hline & XRF & $\mathrm{X}$-ray fluorescence \\
\hline & EnMAP & $\begin{array}{l}\text { Environmental Mapping and Analysis Program: future earth observation satellite mission (http: } \\
\text { //www.enmap.org, last access: } 2 \text { March 2021) }\end{array}$ \\
\hline & CCRSS-A & China Commercial Remote-sensing Satellite System: future earth observation satellite mission \\
\hline & HISUI & Hyperspectral Imager Suite: future earth observation satellite mission \\
\hline \multirow[t]{9}{*}{ Instruments } & HySpex VNIR-1600 & HySpex push-broom spectrometer, VNIR camera \\
\hline & HySpex SWIR-320m-e & HySpex push-broom spectrometer, SWIR camera \\
\hline & HySpex ground & HySpex operational software for laboratory and near-field application \\
\hline & HySpex rad & HySpex calibration software to transform raw digital number into radiance data \\
\hline & $\begin{array}{l}\text { Thermo Scientific } \\
\text { Niton XL3t }\end{array}$ & Thermo Scientific Inc. X-ray fluorescence analyzer (NITON TM XL3t) \\
\hline & NDTr & Thermo Scientific Inc. NITON TM operational software \\
\hline & JEOL JXA-8200 & Electron probe microanalyzer (EPMA) \\
\hline & JEOL JSM-6510 & Scanning electron microscope (SEM) \\
\hline & $\begin{array}{l}\text { Oxford Instruments } \\
\text { INCAx-act }\end{array}$ & Energy dispersive X-ray spectrometer (EDS) \\
\hline \multirow{7}{*}{$\begin{array}{l}\text { Registered brands, } \\
\text { copyrights and/or } \\
\text { other protected terms }\end{array}$} & REacton $^{\circledR}$ & Series of rare-earth metals and compounds \\
\hline & Alfa Aesar & $\begin{array}{l}\text { Manufacturer and supplier of chemicals for research and development (today Thermo Scientific } \\
\text { Inc.) }\end{array}$ \\
\hline & $\begin{array}{l}\text { Gunnar Färber } \\
\text { Minerals }\end{array}$ & Supplier of mineral specimen \\
\hline & REEMAP & $\begin{array}{l}\text { Rare Earth Element Mapping: research project for the development of a modular multi-sensor } \\
\text { processing chain for modern imaging spectrometers to detect REEs }\end{array}$ \\
\hline & Smithsonian Institution & $\begin{array}{l}\text { Smithsonian Institution Department of Mineral Sciences, reference material from the Smithso- } \\
\text { nian Microbeam Standards }\end{array}$ \\
\hline & Astimex Standards Ltd. & $\begin{array}{l}\text { Astimex produces standards suitable for electron probe and scanning electron microscope X-ray } \\
\text { analysis. }\end{array}$ \\
\hline & BVM & $\begin{array}{l}\text { Bureau Veritas Minerals is an industry leader in the analysis of minerals for the exploration and } \\
\text { mining industries. BVM is a service-provider company that provides mineral preparation and } \\
\text { laboratory testing services. }\end{array}$ \\
\hline \multirow{4}{*}{$\begin{array}{l}\text { Research and federal } \\
\text { institutes }\end{array}$} & BGR & Federal Institute for Geosciences and Natural Resources \\
\hline & GSD & $\begin{array}{l}\text { Geological Survey Department, Ministry of Agriculture, Rural Development and Environment, } \\
\text { Republic of Cyprus }\end{array}$ \\
\hline & UP & University of Potsdam \\
\hline & $\begin{array}{l}\text { GFZ } \\
\text { Excel }^{\mathrm{TM}}\end{array}$ & $\begin{array}{l}\text { German Research Centre for Geosciences } \\
\text { Microsoft Excel }\end{array}$ \\
\hline
\end{tabular}


Sample availability. The samples provided by the BGR are available through the collection of the BGR Spandau by their sample and collection name in the technical report (https://gewis.bgr.de/pages/MainApp.aspx?_sys_ params=Nr8PDn_4fNCQfZiUX8sxJCnDDD2DVQI33NH0wD_ j145IzRSaIuClUEeLIBIzpWXeJ7K73GZUfKk, last access: 2 March 2021). The samples provided by the GFZ and UP belong to projects and have to be requested separately.

Author contributions. FK designed the Apliki-sample-related study, performed the measurements of the Apliki samples and wrote the manuscript. NK designed the copper sample study, supervised the measurements and performed the geochemical analysis at the University of Potsdam. CM and AK prepared parts of the spectral libraries. NKB designed the REE study, performed some measurements and supervised the REE measurements. SH prepared the samples and conducted most of the measurements. CR developed and applied the HySpex post-processing chain. CM and KE helped revise the manuscript. UA supervised the studies and gave valuable comments on the manuscript.

Competing interests. The authors declare that they have no conflict of interest.

Acknowledgements. We would like to thank the Helmholtz Centre Potsdam GFZ German Research Centre for Geosciences for providing the infrastructure and personnel support to conduct our research. Our gratitude also goes to the German Federal Ministry of Education and Research and the $\mathrm{r} 4$ subsidy program for innovative technologies for resource efficiency, which supported the REEMAP scientific project. We also want to express our gratitude to Seltenerdmetalle24, in person Manuel Schultz, for his friendly service when providing laboratory standards and negative control sample holder. Thanks to the support by the GSD we were able to conduct a study and sample in the Republic of Cyprus and our thanks go to our colleagues there for their help and directions in the unknown terrain. All the work in the Republic of Cyprus was conducted under the Permit to conduct a Geological Survey, reference no. 02.13.005.002.005.022, from 19 March 2018, granted by the Geological Survey Department, Ministry of Agriculture, Rural Development and Environment (GSD) and the director Costas Constantinou. After the termination of the permit, a memorandum of understanding (MoU) and framework for cooperation in the area of geo-science between the GSD and the GFZ was agreed upon in March 2019; the publication of the Apliki mine surface data is associated with this MoU. Constantin Hildebrand and Friederike Klos prepared parts of the spectral libraries for the data publications and contributed insight into the spectral interpretation. Pia Brinkman prepared the Apliki sample powder tablets. Marcel Horning performed most of the measurements on the copper samples and prepared the spectral copper library during his BS thesis. We thank our colleagues for their input and insights.
Financial support. This research has been supported by the Bundesministerium für Bildung und Forschung (grant no. 033R135) under the scope of the REEMAP project.

Review statement. This paper was edited by Birgit Heim and reviewed by Jeanne Percival and David Turner.

\section{References}

Baldridge, A. M., Hook, S. J., Grove, C. I., and Rivera, G.: The ASTER spectral library version 2.0, Remote Sens. Environ., 113, 711-715, https://doi.org/10.1016/j.rse.2008.11.007, 2009.

Boesche, N., Rogass, C., Lubitz, C., Brell, M., Herrmann, S., Mielke, C., Tonn, S., Appelt, O., Altenberger, U., and Kaufmann, H.: Hyperspectral REE (Rare Earth Element) Mapping of Outcrops - Applications for Neodymium Detection, Remote Sens.Basel, 7, 5160-5186, https://doi.org/10.3390/rs70505160, 2015.

Boesche, N. K., Rogass, C., Mielke, C., Herrmann, S., Körting, F., Papenfuß, A., Lubitz, C., Brell, M., Tonn, S., and Altenberger, U.: Hyperspectral Rare Earth Element Mapping of Three Outcrops at the Fen Complex, Norway: Calcitic, Dolomitic, and Ankeritic Carbonatites, chap. 16, in: Rare Earths Industry - Technological, Economic, and Environmental Implications, Elsevier Inc., 235-265, https://doi.org/10.1016/B978-012-802328-0.00016-4, 2016.

Bösche, N. K.: Detection of Rare Earth Elements and Rare Earth Oxides with Hyperspectral Spectroscopy, University of Potsdam, available at: http://nbn-resolving.de/urn:nbn:de:kobv: 517-opus4-85363 (last access: 2 March 2021), 2015.

Bureau Veritas: Bureau Veritas Metals, Minerals \& Environmental Schedule of Services \& Fees 2020, available at: http://acmelab.com/wp-content/uploads/2020/02/BV_ Fees-Schedule-2020_USD_v3_07Feb2020.pdf (last access: 2 March 2021), 2020.

Clark, R. N.: Spectroscopy of rocks and minerals, and principles of spectroscopy, in: Remote sensing for the earth sciences: Manual of remote sensing, Vol. 3, 3-58, https://doi.org/10.1111/j.19455100.2004.tb00079.x, 1999.

Clark, R. N.: Imaging spectroscopy: Earth and planetary remote sensing with the USGS Tetracorder and expert systems, J. Geophys. Res., 108, 1-2, https://doi.org/10.1029/2002JE001847, 2003.

Clark, R. N., Swayze, G. A., Wise, R. A., Livo, K. E., Hoefen, T. M., Kokaly, R. F., and Sutley, S. J.: USGS Spectral Library splib06a: U.S. Geological Survey, Digital Data Series 231, available at: http://speclab.cr.usgs.gov/spectral.lib06 (last access: 23 June 2009), 2007.

Fisher Scientific:. Thermo Scientific NITON TM XL3t NITON XL3t Specifications, Analysis, available at: https: //www.thermofisher.com/content/dam/LifeTech/Documents/ PDFs/china/Niton-XL3t-GOLDD-Spec-Sheet-2013Jan15.pdf (last access: 18 June 2019), 2002.

Guanter, L., Kaufmann, H., Segl, K., Foerster, S., Rogass, C., Chabrillat, S., Kuester, T., Hollstein, A., Rossner, G., Chlebek, C., Straif, C., Fischer, S., Schrader, S., Storch, T., Heiden, U., Mueller, A., Bachmann, M., Mühle, H., Müller, R., Habermeyer, M., Ohndorf, A., Hill, J., Buddenbaum, H., Hostert, P., Van Der 
Linden, S., Leitão, P. J., Rabe, A., Doerffer, R., Krasemann, H., Xi, H., Mauser, W., Hank, T., Locherer, M., Rast, M., Staenz, K., and Sang, B.: The EnMAP spaceborne imaging spectroscopy mission for earth observation, Remote Sens.-Basel, 7, 8830 8857, https://doi.org/10.3390/rs70708830, 2015.

Heinrich, K. F. J. and Newbury, D. E. (Eds.): Electron probe quantitation, in: Microscopy Microanalysis Microstructures, Plenum Press, New York, https://doi.org/10.1051/mmm:01992003023029500, 1991.

Herrmann, S.: Capacity of Imaging Spectroscopy for the characterisation of REO, REE bearing minerals \& primary REEdeposits, MS thesis, Scientific Technical Report; 19/08, GFZ German Research Centre for Geosciences, Potsdam, vii, 161 pp., https://doi.org/10.2312/GFZ.b103-19089, 2019.

Hunt, G. R.: Spectral signatures of particulate minerals in the visible and near infrared, Geophysics, 42, 501-513, https://doi.org/10.1190/1.1440721, 1977.

Hunt, G. R.: Spectroscopic Properties of Rocks and Minerals, in: Practical Handbook of Physical Properties of Rocks and Minerals, edited by: Carmichael, R. S., CRC Press, Cleveland, Ohio, 599-669, 1989.

Hunt, G. R. and Ashley, R. P.: Spectra of altered rocks in the visible and near infrared, Econ. Geol., 74, 1613-1629, https://doi.org/10.2113/gsecongeo.74.7.1613, 1979.

hyspex.no/products/disc.php: Norsk Elektro Optikk AS HySpex VNIR1600 and SWIR320 m-e:, available at: https://www. hyspex.no/products/disc/vnir-1600.php (last access: 18 June 2019), 2019.

Iwasaki, A., Ohgi, N., Tanii, J., Kawashima, T., and Inada, H.: Hyperspectral Imager Suite (HISUI)-Japanese hyper-multi spectral radiometer, in: International Geoscience and Remote Sensing Symposium (IGARSS), Vancouver, BC, Canada, 1025-1028, 2011.

Jensen, J. R.: Remote Sensing of the Environment An Earth Resource Perspective, 2nd Edn., Pearson Education, Darling Kindersley, South Asia, New Delhi, 2010.

Koellner, N., Koerting, F., Horning, M., Mielke, C., and Altenberger, U.: Technical Report: Mineral reflectance spectra and chemistry of 20 copper-bearing minerals, V. 2.0 GFZ Data Services, https://doi.org/10.5880/GFZ.1.4.2019.003, 2019.

Koerting, F., Herrmann, S., Boesche, N. K., Mielke, C., Koellner, N., and Altenberger, U.: Technical Report: Mineral reflectance spectra and chemistry of 29 rare-earth minerals and rare-earth oxide powders including niobiumand tantalum-oxid powder, V. 2.0 GFZ Data Services, https://doi.org/10.5880/GFZ.1.4.2019.004, 2019a.

Koerting, F., Rogass, C., Koellner, N., Horning, M., and Altenberger, U.: Technical Report: Mineral reflectance spectra and chemistry of 37 copper-bearing surface samples from Apliki copper-gold-pyrite mine in the Republic of Cyprus, V. 2.0 GFZ Data Services, https://doi.org/10.5880/GFZ.1.4.2019.005, 2019b.

Koerting, F., Koellner, N., Mielke, C., Rogass, C., Kuras, A., Altenberger, U., Klos, F., and Hildebrand, C.: Hyperspectral mine face scan of the northern open cut and laboratory scan of surface from the Apliki copper-gold-pyrite mine in the Republic of Cyprus, GFZ Data Services, in preparation, 2021.
Koerting, F. M.: Hybrid imaging spectroscopy approaches for open pit mining - Applications for virtual mine face geology, $\mathrm{PhD}$ thesis, University of Potsdam, 2021.

Körting, F.: Development of a $360^{\circ}$ hyperspectral drill core scanner Test of technical conditions and validation of high-resolution near-field analysis of crystalline basement rocks using COSC-1 core samples, MS thesis, Scientific Technical Report, 19/07, GFZ German Research Centre for Geosciences, Potsdam, 97, xxi pp., https://doi.org/10.2312/GFZ.b103-19071, 2019.

Kokaly, R. F., Clark, R. N., Swayze, G. A., Livo, K. E., Hoefen, T. M., Pearson, N. C., Wise, R. A., Benzel, W. M., Lowers, H. A., Driscoll, R. L., and Klein, A. J.: USGS Spectral Library Version 7, available at: https://pubs.er.usgs.gov/publication/ds1035 (last access: 2 March 2021), 2017.

Lorenz, M., Altenberger, U., Trumbull, R. B., Lira, R., Luchi, M. L. De, Günter, C., and Eidner, S.: Chemical and textural relations of britholite- and apatite-group minerals from hydrothermal REE mineralization at the Rodeo de los Molles deposit, Central Argentina, Am. Mineral., 104,1840-1850, https://doi.org/https://doi.org/10.2138/am-2019-6969, 2019.

Meerdink, S. K., Hook, S. J., Roberts, D. A., and Abbott, E. A.: The ECOSTRESS spectral library version 1.0, Remote Sens. Environ., 230, 111196, https://doi.org/10.1016/j.rse.2019.05.015, 2019.

Mielke, C., Rogass, C., Boesche, N., Segl, K., and Altenberger, U.: EnGeoMAP 2.0-Automated Hyperspectral Mineral Identification for the German EnMAP Space Mission, Remote Sens-Basel, 8, 127, https://doi.org/10.3390/rs8020127, 2016.

Percival, J. B., Olejarz, A. D., English, M. L. R., Belley, P. M., Flynn, T., Laudadio, A. B., Stirling, J. A., and Stirling, J. A. R.: The National Mineral Reference Collection (NMC) Digital Spectral (VIS-NIR-SWIR) Library. Part I: The Kodama clay mineral collection, Geological Survey of Canada, Open File 7923, 24 pp., https://doi.org/10.4095/297564, 2016.

Rogass, C., Koerting, F. M., Mielke, C., Brell, M., Boesche, N. K., Bade, M., and Hohmann, C.: Translational imaging spectroscopy for proximal sensing, Sensors (Switzerland), 17, 1857, https://doi.org/10.3390/s17081857, 2017.

Swayze, G. A., Clark, R. N., Goetz, A. F. H., Livo, K. E., Breit, G. N., Kruse, F. A., Sutley, S. J., Snee, L. W., Lowers, H. A., Post, J. L., Stoffregen, R. E., and Ashley, R. P.: Mapping advanced argillic alteration at Cuprite, Nevada, using imaging spectroscopy, Econ. Geol., 109, 1179-1221, https://doi.org/10.2113/econgeo.109.5.1179, 2014.

Tong, Q., Xue, Y., and Zhang, L.: Progress in hyperspectral remote sensing science and technology in China over the past three decades, IEEE J. Sel. Top. Appl., 7, 70-91, https://doi.org/10.1109/JSTARS.2013.2267204, 2014.

Turner, D., Rivard, B., and Groat, L.: Rare earth element ore grade estimation of mineralized drill core from hyperspectral imaging spectroscopy, in: 2014 IEEE Geoscience and Remote Sensing Symposium, 4612-4615, 2014a.

Turner, D. J.: Reflectance spectroscopy and imaging spectroscopy of rare earth element-bearing mineral and rock samples, Doctor of Philosophy Thesis, University of British Columbia, Vancouver, April 2015. 
Turner, D. J., Rivard, B., and Groat, L. A.: Visible and short-wave infrared reflectance spectroscopy of REE fluorocarbonates, Am. Mineral., 99, 1335-1346, https://doi.org/10.2138/am.2014.4674, 2014b.

van der Meer, F. D., van der Werff, H. M. A., van Ruitenbeek, F. J. A., Hecker, C. A., Bakker, W. H., Noomen, M. F., van der Meijde, M., Carranza, E. J. M., de Smeth, J. B., and Woldai, T.: Multi- and hyperspectral geologic remote sensing: A review, Int. J. Appl. Earth Obs., 14, 112-128, https://doi.org/10.1016/j.jag.2011.08.002, 2012. 